\title{
La construcción visual de la felicidad y la convivencia familiar en México: los anuncios publicitarios en la prensa gráfica (1930-1970)
}

\author{
SUSANA SOSENSKI \\ Instituto de Investigaciones Históricas \\ Universidad Nacional Autónoma de México \\ sosenski@unam.mx \\ RICARDO LÓPEZ LEÓN \\ Centro de Ciencias del Diseño y de la Construcción \\ Universidad Autónoma de Aguascalientes \\ ricardolopezleon@gmail.com
}

\begin{abstract}
Resumen
En este artículo se analizan las formas en que la publicidad gráfica aparecida en la prensa mexicana entre 1930 y 1970 asoció la idea de felicidad con un modelo de convivencia familiar. La publicidad atribuyó cualidades afectivas y emocionales a ciertos objetos ubicados en espacios determinados y construyó imaginarios y representaciones sobre lo que significaba una vida familiar feliz que homogeneizaban un modelo de felicidad familiar. El marco temporal propuesto permite observar la transformación de las relaciones matrimoniales y paternofiliales.
\end{abstract}

Palabras clave: felicidad; publicidad; infancia; familia; convivencia.

\section{The Visual Construction of Happiness and Family Coexistence in Mexico: Advertisements in the Graphic Press (1930-1970)}

\begin{abstract}
This article studies the ways in which graphic advertisements in the Mexican press between 1930 and 1970 associated the idea of happiness with a model of family coexistence. Advertising attributed affective and emotional qualities to certain objects located in specific spaces, and constructed imaginaries and representations of a happy family life that homogenized a model of domestic bliss. The time framework selected makes it possible to study the transformation of marital and paternal relationships.
\end{abstract}

Key words: happiness; advertising; childhood; family; coexistence. 


\title{
La construcción visual de la felicidad y la convivencia familiar en México: los anuncios publicitarios en la prensa gráfica (1930-1970)
}

\author{
Susana Sosenski y Ricardo López León
}

\section{INTRODUCCIÓN}

$\mathrm{E}$ 1 consumo y la publicidad se erigieron a lo largo del siglo XX como dos grandes componentes de la vida cotidiana en México. El consumo pensado como un engranaje del proceso productivo, pero también como un conjunto de prácticas a través de las cuales se aspiraba a satisfacer deseos y necesidades, denotar estatus o distinción se vinculó con herramientas y estrategias publicitarias. Los carteles en las calles, los anuncios en radio y televisión y la publicidad en la prensa mexicana, entre otros, dan cuenta de los caminos por los que México transitó por la ruta de la modernización a lo largo del siglo XX.

El contexto signado por los efectos de la crisis económica mundial de 1929, cuyas consecuencias fueron el desempleo, los bajos salarios, el retorno de migrantes, la baja producción y el cierre de fábricas, hizo que la felicidad de niños, mujeres y hombres se convirtiera, parafraseando a Bertrand Russell, en una de las emociones a ser conquistadas, y por ende una de las más explotadas por el mundo publicitario. El encuentro discursivo entre el consumo y la felicidad hizo de estos un binomio inseparable hasta nuestros días. La felicidad apareció como uno de los sinónimos de la modernidad que, con la adquisición de objetos, podía ser mensurable.

De tal modo, la publicidad se encargó de construir representaciones e imaginarios de un México posible, de un "México feliz", de un "mundo alterno" dominado por emociones como la felicidad, el amor, la alegría y el entusiasmo conseguidos fácilmente a través del consumo, mientras, en contraste, los efectos del "milagro mexicano" (periodo caracterizado por un crecimiento económico alto y sostenido entre 1940 y 1970) no llegaban a toda la población mexicana. ${ }^{1}$ El consumo de las crecientes clases medias no pudo ocultar que en muchas regiones del país y de la propia capital se vivían condiciones de pobreza y miseria tan profundas como las que había retratado el cineasta español Luis Buñuel en Los olvidados (1951).

\footnotetext{
${ }^{1}$ Cabe mencionar que muchos anuncios publicitarios eran reproducidos en varios países de América Latina de anuncios originales creados en Estados Unidos, por lo que la historiografía todavía tiene pendiente identificar cuáles son los puntos de coincidencia y las especificidades que vivió la publicidad en los diversos países de la región. Podemos sugerir que la idea de crear "mundos alternos" publicitarios en los que la felicidad era el objetivo central logrado a través del consumo, pudo haberse repetido en varias naciones y ser una idea compartida, transnacional.
} 
Entre 1930 y 1970 fueron miles los anuncios que se publicaron en la prensa. Uno de los atributos más importantes de la publicidad gráfica en ese periodo fue el singular diálogo que se estableció entre imagen y texto; en ocasiones la imagen o la gráfica fue dispuesta para acompañar al texto, en otras fue el texto el que acompañó a la imagen, con frecuencia imagen y texto pretendieron ser discursos afines pero muchas veces parecían desvinculados entre sí. Es importante resaltar que los anuncios analizados aquí fueron seleccionados bajo el criterio de que de una u otra manera apareciera la representación de la felicidad en la imagen o el texto (generalmente a través de las sonrisas), aunque también se analizaron anuncios publicitarios que presentaran las antípodas de la felicidad (ira, enojo, tristeza). ${ }^{2}$

La publicidad y su relación con el uso y manejo de las emociones no era una novedad para los años que nos interesan. El

\footnotetext{
${ }^{2}$ Nos hemos concentrado en la publicidad publicada por los grandes diarios de circulación nacional: El Universal, El Universal Gráfico, Excélsior, La Prensa y Novedades en el entendido de que, aunque la calidad de impresión de los anuncios es menor, pudieron haber tenido un público de lectores más amplios que las revistas ilustradas. Como señalaba en 1955 el publicista estadounidense Harry Walker Hepner (1962), autor de Psychology in modern business, "los periódicos llegan a todas las clases sociales. Aproximadamente $90 \%$ de todas las familias [estadunidenses] leen el periódico, pero únicamente alrededor de $50 \%$ lee revistas [...] en segundo lugar, los periódicos son publicados diariamente; por tanto los anuncios pueden ser preparados y publicados con mayor rapidez que en una revista. Esto da al anunciante mayor dominio sobre su campaña" (p. 215). Thomas S. Hunter (1954, pp. 126-132) coincidía con su colega en el éxito publicitario que ofrecían los periódicos.
}

austriaco Edward Bernays (1891-1995), especialista en publicidad y propaganda, pionero en el campo de las relaciones públicas en Estados Unidos, era sobrino de Sigmund Freud. Bernays, radicado en Estados Unidos desde su infancia, había leído con avidez los trabajos de su tío, textos que le hicieron pensar la importancia del manejo de las emociones y del inconsciente como una poderosa herramienta para el mundo publicitario. La manipulación emocional permitiría atraer a más consumidores al proceso de compra y modificar no sólo estilos de vida y comportamientos sino también deseos y formas de pensar de ciertos sectores, generalmente urbanos. Bernays logró convencer a su tío no sólo de ser su agente en Estados Unidos y manejar los derechos de sus obras en aquel país, sino también de traducir sus libros, ${ }^{3}$ entre ellos La psicología de las masas, que se convirtió en el texto de cabecera de los publicistas de los años treinta (Freud et al., 1993, p. 385). ${ }^{4}$ De tal forma, las emociones, los deseos, la mente y el inconsciente se convirtieron en los ejes sobre los cuales trabajarían los publicistas (Curtis, 2006). Entre 1930 y 1940 los hombres de negocios, que habían vivido de cerca los efectos de la Gran Depre-

3 Así, publicó A General Introduction to Psichoanalysis en 1920, con una traducción hecha por él mismo pero que atribuyó desde la primera página al destacado psicólogo estadounidense Stanley Hall. El psicoanalista inglés Ernest Jones había calificado de inescrupuloso a Bernays y de tendenciosa, indigna, coloquial y plagada de vulgares americanismos a su traducción. Curtis (2006); Freud, Jones y Paskauskas (1993).

${ }^{4}$ Incluso, para aumentar el número de ventas, el sobrino había puesto en la primera página que la traducción había sido hecha por el famoso psicólogo estadunidense Stanley Hall. 
sión, iniciaron "estudios profundos para satisfacer el gran mercado básico” (Villamil, p. 136) comenzaron a estudiar el comportamiento del público, de los consumidores, a investigar sobre "los hábitos de consumo, los hábitos de lectura de diarios y revistas", qué clases económicas escuchaban radio y a qué hora lo hacían; pedían opiniones, averiguaban qué tipo de productos se preferirían o cuáles debían ser sus características, es decir "todas las actividades, sistemas y técnicas para comprar y vender" (Villamil, p. 136).

Si para la década de 1930 los anuncios publicitarios estaban con frecuencia compuestos por imágenes pero acompañados de largos textos informativos y la imagen no lograba sustituir al lenguaje textual, hacia 1950 ya era posible advertir la paulatina reducción del texto en función de un crecimiento de la imagen y la aplicación de la psicología. Estos avances coincidieron con el fin de la guerra y la hegemonía de Estados Unidos en el continente americano, donde se distribuyeron masivamente los productos estadunidenses a través de las campañas publicitarias emprendidas por lo que serían las más importantes empresas publicitarias de la posguerra: J. Walter Thompson, Young \& Rubicam y Mc. Cann-Ericson, entre otras. En ese sentido, el periodo que va desde 1930 hasta 1970 fue un momento signado por el fortalecimiento del capitalismo industrial moderno en México, en donde la publicidad, las nuevas formas de entretenimiento, el nacimiento de medios masivos de comunicación como la televisión, la consolidación tecnológica de los medios que ya existían (prensa y radio), el surgimiento de nuevos espacios destinados al consumo, la entrada de compañías y productos estadunidenses, la insistencia en hacer de México un país competitivo en el mercado internacional a través de programas de corte nacionalista y capitalista (como la campaña "Hecho en México”), la orientación del país hacia el consumo y lo urbano, redefinieron los procesos identitarios de las clases medias mexicanas (véanse Bunker y MacíasGonzález, 2011; Moreno, 2003). Todo eso hizo que entre 1940 y 1970 ocurriera lo que Steven Bunker y Víctor MacíasGonzález (2011) decidieron llamar "la edad de oro del consumo" en México (p. 91). Todas estas características dotan de gran riqueza cultural y económica al periodo que hemos elegido como corte temporal para nuestro análisis. ${ }^{5}$

La publicidad mexicana del periodo que nos interesa no puede ser entendida sin una mirada bifocal que atienda a dos procesos fundamentales: por un lado la "norteamericanización de las costumbres", caracterizada por las influencias transculturales de gran magnitud que aparecieron en el lenguaje, la comida, las formas de vestir, y que permearon muchos de los aspectos de la vida cotidiana de los mexicanos; y, por otro lado, las creaciones y apropiaciones particulares que hicieron los mexicanos de la cultura del consumo. Hacia 1950 el american way of life apareció como el símbolo de la modernización, como el estilo de vida que se vinculaba a las clases medias y altas y que se configu-

${ }^{5}$ Es importante mencionar que los anuncios citados en este trabajo son sólo una selección de los más de 500 anuncios publicitarios que analizamos en nuestra revisión hemerográfica. En esta revisión cubrimos los años que van de 1930 a 1970 , por lo tanto los argumentos planteados en este artículo obedecen a esa mirada amplia de la publicidad gráfica en la prensa del periodo. 
raba en gran medida por la capacidad de consumo, entre otras cosas de electrodomésticos, automóviles y comida enlatada. La publicidad aparecida en la prensa mexicana de estos años se produjo en un contexto de una enorme influencia cultural estadunidense en la vida cotidiana. Desde 1931 el estadunidense Stuart Chase, en un libro ilustrado por Diego Rivera e intitulado provocadoramente: México: Estudio de dos Américas, ya advertía la penetración de la cultura estadunidense en México:

Entre las palabras están sándwiches, flapper, mitin, líder, ya que no tienen palabra para el dirigente civil, aunque las hay para el político y el militar. Spot, dumping, boicot, futbol, golf, beisbol, umpire, pitcher, bat, bateador, box, matches, pullman, sleepings, smokings, foxtrot, socket, switch y términos de electricidad en general.

En México lo distinguido es copiar al norte: Jazz Country Club. De los periódicos principales de México y de las 4196 pulgadas de anuncios desplegados, en dos dominicales de un día de diciembre de 1930 , 2509 pulgadas se dedican a productos norteamericanos; 1056 a productos mexicanos y 631 a productos europeos o no identificados. Los artículos norteamericanos aparecen dos a uno en relación a los mexicanos y cinco a uno en relación a los europeos. Entre lo norteamericano anunciado encontramos artículos en el siguiente orden: equipos para el hogar, principalmente radios y aparatos eléctricos; maquinaria, principalmente automóviles; cámaras, máquinas para escribir; armas de fuego; películas de Hollywood; cosméticos y jabones; medicinas de patente; ropa y textiles, medias de seda, camisas y cuellos; sombreros Stetson; viajes; relojes y joyería; escuelas e instrucción; equipo para hoteles, principalmente artículos de baño y plome- ría. ¿No se siente uno en casa? (Villamil, 1971, p. 127).

En el ámbito publicitario la presencia estadunidense era muy clara, ya que muchos de los productos anunciados en México provenían de marcas y empresas del vecino país (Kodak, Westinghouse, Cadillac, etc) que, para ahorrar costos, reutilizaban sus anuncios en función de la lengua o costumbres locales. Esto provocó que numerosos anuncios en el continente americano fueran reproducciones, reformulaciones o simplemente traducciones de versiones estadunidenses. ${ }^{6}$ Cabe mencionar que, independientemente de que los publicistas, dibujantes o creativos de los anuncios en la prensa fueran difíciles de identificar, pues en la mayoría de las publicaciones no se les daba crédito a los ilustradores (Villamil, 1971), es posible reconocer algunas empresas mexicanas dedicadas al diseño e impresión de productos publicitarios. Estos elementos invitan a reflexionar sobre la expresión de lo mexicano y lo nacional en los anuncios, pero especialmente permite analizar las dinámicas entre representaciones y prácticas, es decir, identificar cuáles eran los hábitos y costumbres que recuperaban los anuncios, cuáles los imaginarios y los estereotipos que divulgaron.

La publicidad ha sido un tema al que la historiografía mexicana ha considerado marginal, a pesar de que contemos con valiosos avances en la materia (Ballent, 1996, pp. 53-74; Hellion, 2008;

${ }^{6}$ En 1946 había 34 agencias de publicidad en la capital mexicana, muchas de ellas estadunidenses, como la J. Walter Thompson Company. Véanse Salvatore (2005, pp. 216-235); Woodard (2002, pp. 257-290). 
Loyo, 2007, pp. 349-384; Matute, 2006, pp. 157-176; Ortiz, 1998, pp. 411-435, 2003, 2006, pp. 117-155). ${ }^{7}$ Los estudios que abordan la historia de la publicidad en México generalmente toman la imagen publicitaria como un documento histórico para observar las mentalidades de cierta época, los hábitos, las costumbres o las tendencias artísticas; sin embargo, se ha dejado de lado la práctica educadora de la publicidad como formadora de prácticas y experiencias tanto en el orden doméstico como en el mundo de las emociones, la sociabilidad o las formas de relacionarse dentro de la familia, temas que nos preocupan en el presente texto. Consideramos que la publicidad, si bien expresó y develó una realidad múltiple y compleja, especialmente se convirtió en una agencia educativa no formal que pudo haber incidido en las representaciones, imaginarios y prácticas de las familias, aunque esto sea todavía difícil de documentar.

Desde las primeras décadas del siglo $x x$ la familia mexicana se convirtió en una imagen publicitaria recurrente. Como nunca antes, las imágenes de padres, madres e hijos juntos atiborraron los anuncios en la prensa nacional. El niño adquirió una importancia poco vista hasta entonces, que coincidía, no fortuitamente, con una serie de construcciones que se resumían en que el siglo Xx, como había dicho la pedagoga sueca Ellen Key, era "el siglo del niño". ${ }^{8}$ De tal forma, centraremos nuestro análisis en la representación publicitaria de la familia y en su

\footnotetext{
7 Se encuentran en curso, en distintas instituciones, varias tesis de posgrado sobre este tema.

${ }^{8}$ Para mayores referencias sobre la historia de la infancia en México en la vuelta de siglo, véase Castillo (2006).
}

vínculo con la idea de felicidad, en tanto el consumo se ligó estrechamente con la idea de felicidad familiar. La publicidad de estos años presentó un ideal de familia feliz consumidora (una "familia posible") representada generalmente por una madre hogareña, un padre proveedor y dos hijos (una niña y un niño).

\section{LA CONVIVENCIA FAMILIAR COMO REPRESENTACIÓN DE LA FELICIDAD}

Las políticas económicas de los gobiernos de mediados del siglo xx generaron lo que muchos consideraron un "milagro"; es decir, un crecimiento económico sin precedentes. El país se orientó al consumo y se privilegió la consolidación económica de los sectores medios urbanos. Serían precisamente esos sectores los principales destinatarios de la publicidad gráfica en la prensa. Se partía de la idea de que las familias de clase media podrían gozar de cierta comodidad económica, salir de día de campo, tener un pollo entero para comer o tiempo para el disfrute entre padres e hijos, imágenes reiteradas por la publicidad. Un amplio grupo de mexicanos en la década de 1940, como señaló Julio Moreno (2003), juzgaba su éxito o fracaso personal a partir de su posibilidad de adquirir bienes materiales, definían su estatus social a través del lente de la "cultura del consumo" (p. 207).

Para los publicistas el mejor recurso para vender los productos ha sido apelar a las emociones de su público. El dolor, la ira, la tristeza, la alegría o la felicidad fueron emociones comúnmente utilizadas. La felicidad pareció convertirse en la meta, en el fin último del individuo moderno. Y se vinculó estrechamente con la idea de 
la convivencia familiar. Los productos anunciados prometían la posibilidad de mantener unida a la familia y, en consecuencia, abrían también la posibilidad de ser feliz. Es decir, para la construcción de la idea de felicidad la convivencia familiar generada por el consumo resultó ser fundamental. El consumo aparecía en estos años, en casi toda América Latina, como la solución universal para todos los males (Brites, 2000, pp. 249-278).

En la sociedad de consumo el ocio y el uso del tiempo libre cobraban una importancia peculiar. El núcleo familiar debía ser provisto de espacios y tiempos para ello. La convivencia familiar se presentaba como posibilidad en tanto tuviera un espacio específico para el encuentro y la recreación, para el consumo y el disfrute de los objetos: de las cosas. La publicidad atribuyó a lo largo de los años cualidades afectivas a los objetos que les daban vida (Brites, 2000, p. 251). Pero, además de necesitar un espacio, la convivencia familiar requería tiempo, un tiempo que debían dedicar tanto las madres como los padres para estar con los hijos y con la familia. Nuestra hipótesis es que la publicidad no apeló a ni representó las múltiples y heterogéneas formas de convivencia que podían darse en México, sino al contrario, unificó, homogeneizó y presentó modelos muy específicos y reiterados de lo que se consideraba una convivencia familiar feliz en la que el hombre ostentaba una posición jerárquica muy definida, y la mujer era representada casi siempre en un papel hogareño y dedicada a las labores de la casa y del cuidado de los niños. En suma, la publicidad a lo largo de estas décadas construyó una imagen estereotipada de la familia mexicana, que aludía a una clase media y alta, con poder adquisitivo, con un padre trabajador fuera del hogar, una madre dedicada a las labores de la casa, y dos hijos, generalmente un niño y una niña.

La fotografía desempeñó un papel fundamental en la construcción publicitaria de la felicidad y en la construcción de imaginarios en torno a lo que era ser feliz en México. Y lo hizo en dos vías. Tanto en la producción de imágenes publicitarias que serían consumidas, como en la posibilidad que ofrecía a los consumidores al presentarse como una revolución tecnológica que podían usar hombres, mujeres y niños y un adelanto capaz de registrar para la posteridad las escenas más íntimas, cálidas y espontáneas de la vida en familia o incluso fomentar habilidades estéticas entre los fotógrafos aficionados (generalmente hombres). Como lo muestra Claudia Pretelin (2010), los esfuerzos publicitarios de la Kodak en Estados Unidos fueron exhaustivos para lograr que la cámara se convirtiera en un objeto necesario y la fotografía una práctica de la vida cotidiana. Desde material en medios masivos hasta manuales y otros impresos, la Kodak prometía ser un instrumento de uso fácil, disponible para todo tipo de actividades dentro y fuera del hogar y al alcance de toda la familia. En México, su presencia es particularmente notable desde los tempranos años veinte publicitando sus cámaras de manera constante en la prensa, anunciándolas como máquinas modernas y herramientas artísticas, pero también como poderosos instrumentos de reproducción de instantes. Esta empresa construyó un vínculo muy estrecho entre sus cámaras y la idea de convivencia familiar y lo convirtió en uno de sus ejes publicitarios y casi en una campaña didáctica. Kodak se erigió como cronista de la vida 
infantil, y sus anuncios constantemente resaltaron uno de los atributos de la fotografía, la inmortalidad de las escenas, así dictaban a sus consumidores las imágenes que valía la pena conservar para siempre. En tanto la película fotográfica no era un producto que pudiera utilizarse indiscriminadamente, cada escena capturada por la cámara portátil debía valer la pena por el gasto que representaría revelarla e imprimirla. Y muchas de las escenas preferidas de Kodak estaban signadas por la felicidad y la convivencia familiar. En ese sentido, la publicidad de la cámara Kodak (véase figura 1) desempeñó un papel importante: permitió dejar testimonios gráficos de toda una época, fijar las imágenes para el futuro, pero además de su sentido literal, también propuso imágenes de los modelos de felicidad familiar (véase Taylor, 1994, pp. 29-42). ${ }^{9}$

\section{EL NIÑO COMO UNA DE LAS CLAVES DE LA} FELICIDAD PUBLICITARIA

A lo largo del siglo xx el juego de los niños se convirtió en una de las principales discusiones de pedagogos y psicólogos en el mundo occidental. En la época que estudiamos proliferaron los libros y manuales para el cuidado del bebé y del niño que fomentaban, entre muchas otras cosas, un sentimiento familiar de que todos debían estar pasándosela bien. Esto provocó lo que algunos historiadores, como Peter Stearns (2003), han descrito como un ascendente proceso de "ansiedad paterna",

\footnotetext{
${ }^{9}$ El autor analiza cómo la fotografía publicitaria se convirtió en un medio no sólo de retener memorias felices de familia sino de presentar nuevas ideas de lo femenino, y de inventar la "kodak girl".
}

sobre todo si las cosas en casa no marchaban de acuerdo con los manuales. En un esfuerzo por datar los inicios de la asociación entre infancia y felicidad, Stearns (2010, pp. 165-166) encontró que fue a finales del siglo XIX y principios del siglo XX, pero especialmente durante la década de 1920 en Estados Unidos, cuando se mostró una explosión de referencias a la felicidad infantil. Las canciones de cumpleaños, los anuncios de crianza infantil pero especialmente los manuales de cuidado de niños fueron los principales generadores del discurso sobre la felicidad. Esto claramente no significa que los niños comenzaran a ser felices en ese entonces, sino que sugiere que en épocas previas la felicidad no era vista como una obligación de los padres o los adultos hacia los niños, es decir, no se asociaba a la infancia con una etapa feliz en el desarrollo humano. Para los años cuarenta la felicidad ya estaba completamente asociada con la infancia, a tal grado que la imagen de los niños, especialmente los bebés, fue insistentemente utilizada para vender productos a los adultos (véase Hunter, 1954, p. 36). La publicidad fue un poderoso agente de construcción del vínculo entre infancia y felicidad.

La felicidad infantil se asoció muy pronto con el juego. María Montessori y Jean Piaget, entre otros, insistieron en que el juego era parte esencial del desarrollo emocional e intelectual del niño, discursos pedagógicos que se reforzaron después de la segunda guerra. El juego fue inevitablemente acompañado de la compra de juguetes, que aparecieron como objetos constructores de identidad. No sólo la publicidad de juguetes hizo énfasis en estas ideas. Compañías de luz aseguraron en sus anuncios que el suministro de energía 


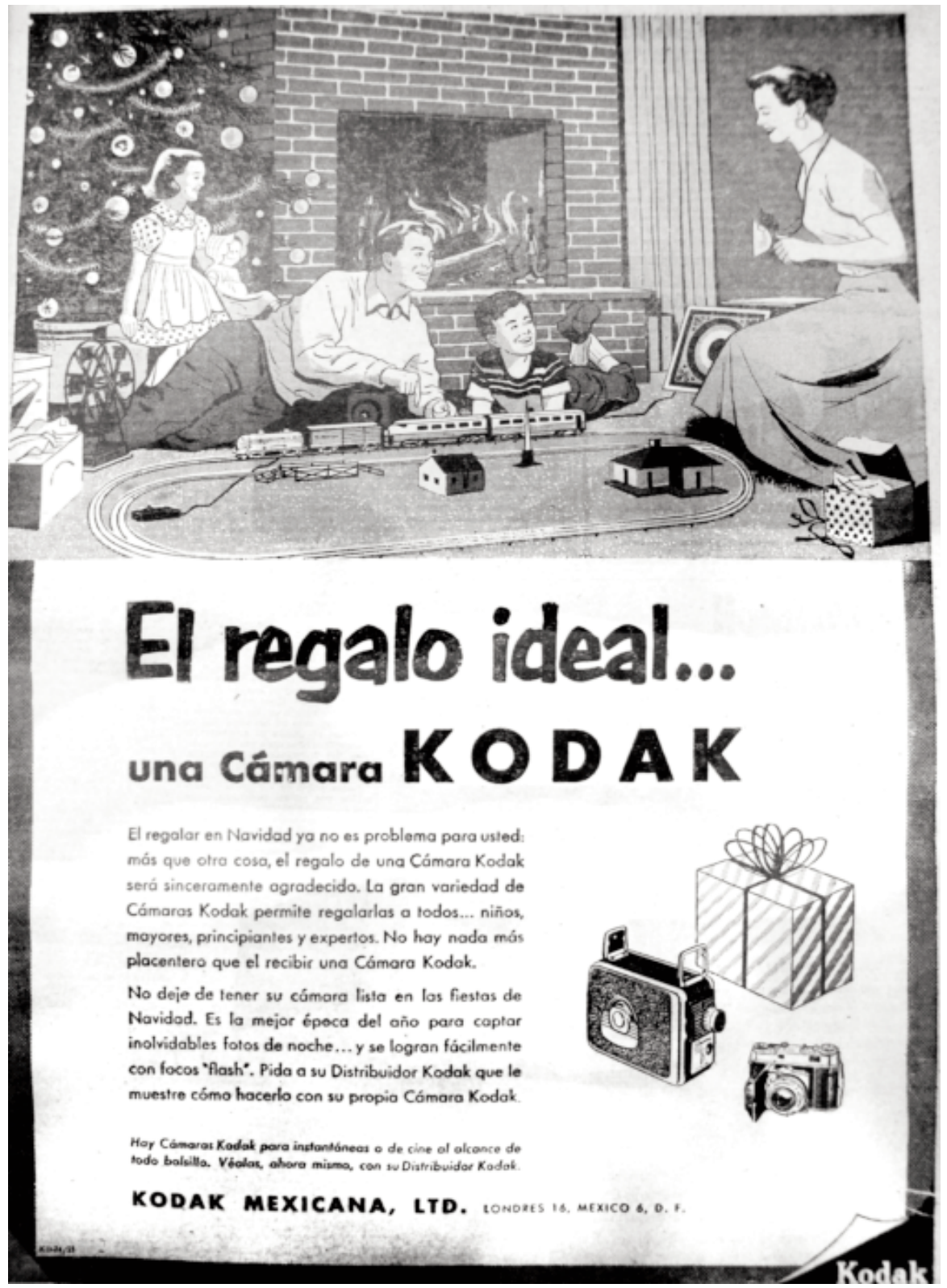

Figura 1. Anuncio Kodak. Fuente: La Prensa, 10 de diciembre de 1953.

\section{(ㅇ)(1)(8)}


eléctrica era fundamental para mantener el juego y la convivencia. Empresas fotográficas utilizaron discursos similares para indicar que esos momentos de encuentro entre padres e hijos eran uno de los instantes que debían conservarse en la memoria visual. Así, la publicidad hizo eco de los discursos psicopedagógicos y si los manuales de cuidado de los hijos subrayaban que los niños debían estar rodeados de juguetes, la publicidad ofreció estos y otros muchos objetos.

Si los niños debían jugar, también debían tener un espacio ideal para hacerlo. Los niños, representados como los hombres y mujeres del futuro, fueron entonces un gancho emotivo entre el consumidor adulto y las empresas de bienes raíces y fraccionadoras que proliferaban en México en ese periodo. En tanto lugar simbólico de futuro, la figura del niño se utilizó para explotar las emociones de sus padres. Niños, futuro y felicidad se convertían en una tríada a cuidar. La publicidad insistía en que los gastos debían estar enfocados al cuidado de la descendencia. ${ }^{10}$ Es por ello que las imágenes de niños sonrientes, jugando o estudiando se multiplicaron en los anuncios publicados en revistas y periódicos. Si debía comprarse una casa o un terreno, era para demostrar que se era buen padre, pero también para evidenciar la genuina preocupación por el bienestar de los hijos al brindarles lugares seguros para jugar y ser felices. La fraccionadora de terrenos de Granjas San Antonio en la ciudad de México (véase figura 2), por ejemplo, anunciaba la zona no sólo como "el fraccionamiento más perfecto de la época” sino como un lugar para

10 Anuncio. El Universal, 21 de abril de 1957, p. 5, ciudad de México. vivir "momentos felices". "Sienta la dicha de ver a sus hijos felices y fuertes disfrutando de la vida del campo", rezaba uno de sus anuncios. Estos "momentos" se representaban con una imagen que ocupaba la mitad del anuncio, en la que una niña rubia sentada en el pasto, rodeada de patos y gallinas, abrazaba un corderito y miraba a la lejanía.

La convivencia familiar y su vínculo con la felicidad fueron utilizados de manera recurrente por la publicidad de fraccionadoras e inmobiliarias. Un anuncio del fraccionamiento Campestre Churubusco, también en la capital (véase figura 3) presentaba una foto en la que una familia disfrutaba tranquila, alegre y en paz de un día soleado y miraba un estanque. El hijo más pequeño es detenido por el padre, mientras que el más grande juega al borde del agua con un barco de papel. El discurso textual parece dirigirse al padre, ya que subraya la seguridad de los ahorros y de la inversión, así como la segura plusvalía de la zona. En este lugar se había planeado "todo lo que sus bijos necesitan para crecer sanos” (véase figura 4): aire puro, pistas para patinar, canchas para juegos de pelota, calles onduladas que impiden altas velocidades en los vehículos, parques y jardines, centros educacionales, avenidas pavimentadas y líneas de camiones. La publicidad de la colonia Jardín Balbuena en la ciudad de México (véase figura 5) utilizó la imagen de dos niños corriendo presurosos, felices y tranquilos que podrían ir a la escuela "sin correr peligros" sin "atravesar calles de tránsito", porque "cada manzana de este superfraccionamiento [estaba planeada] técnicamente para que los niños tengan aire, sol y grandes espacios abiertos destinados a su diversión". Los padres podrían "vivir 


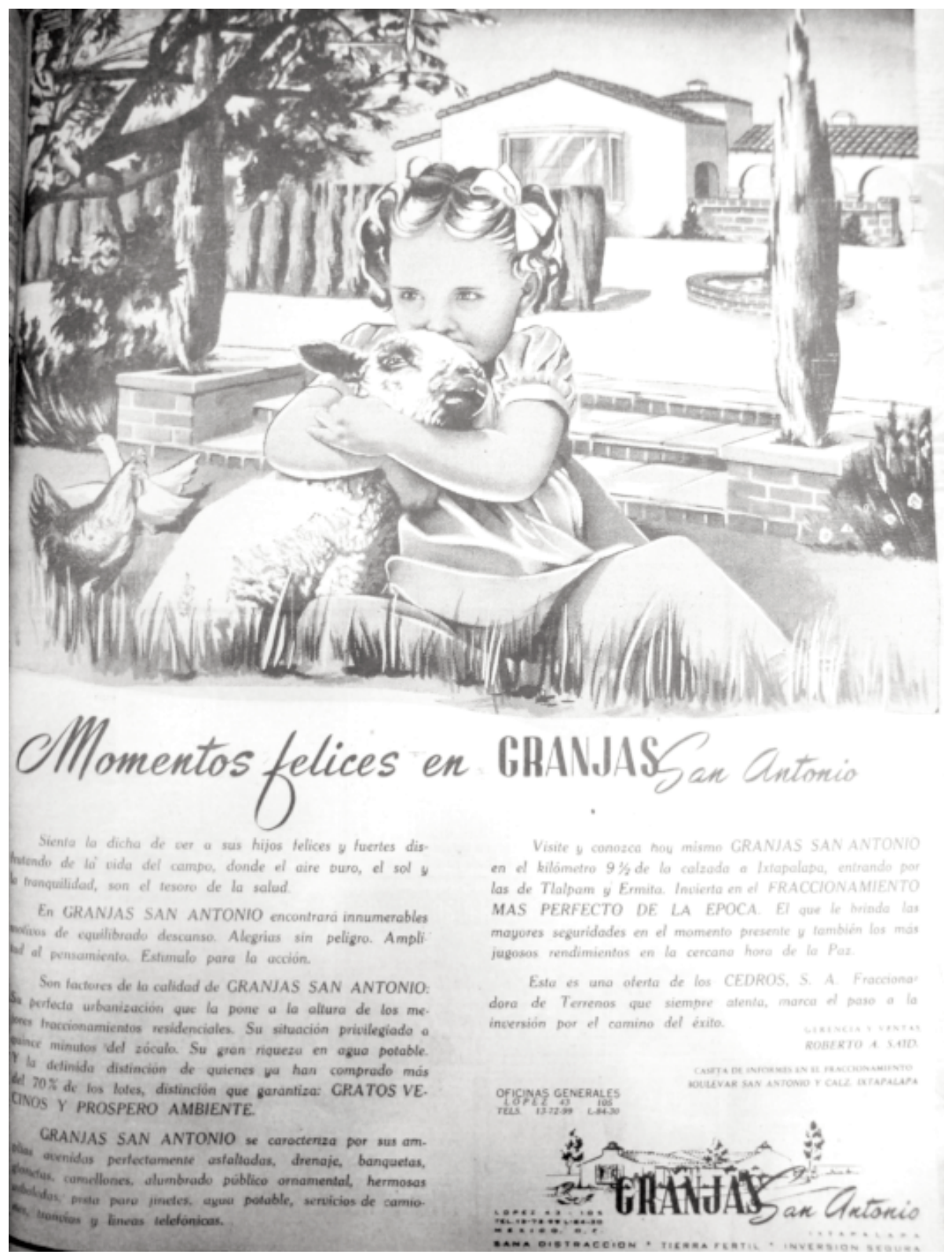

Figura 2. Anuncio Granjas San Antonio. Fuente: El Universal, 15 de abril de 1945.

\section{(ㅇ)(1) $(8$}




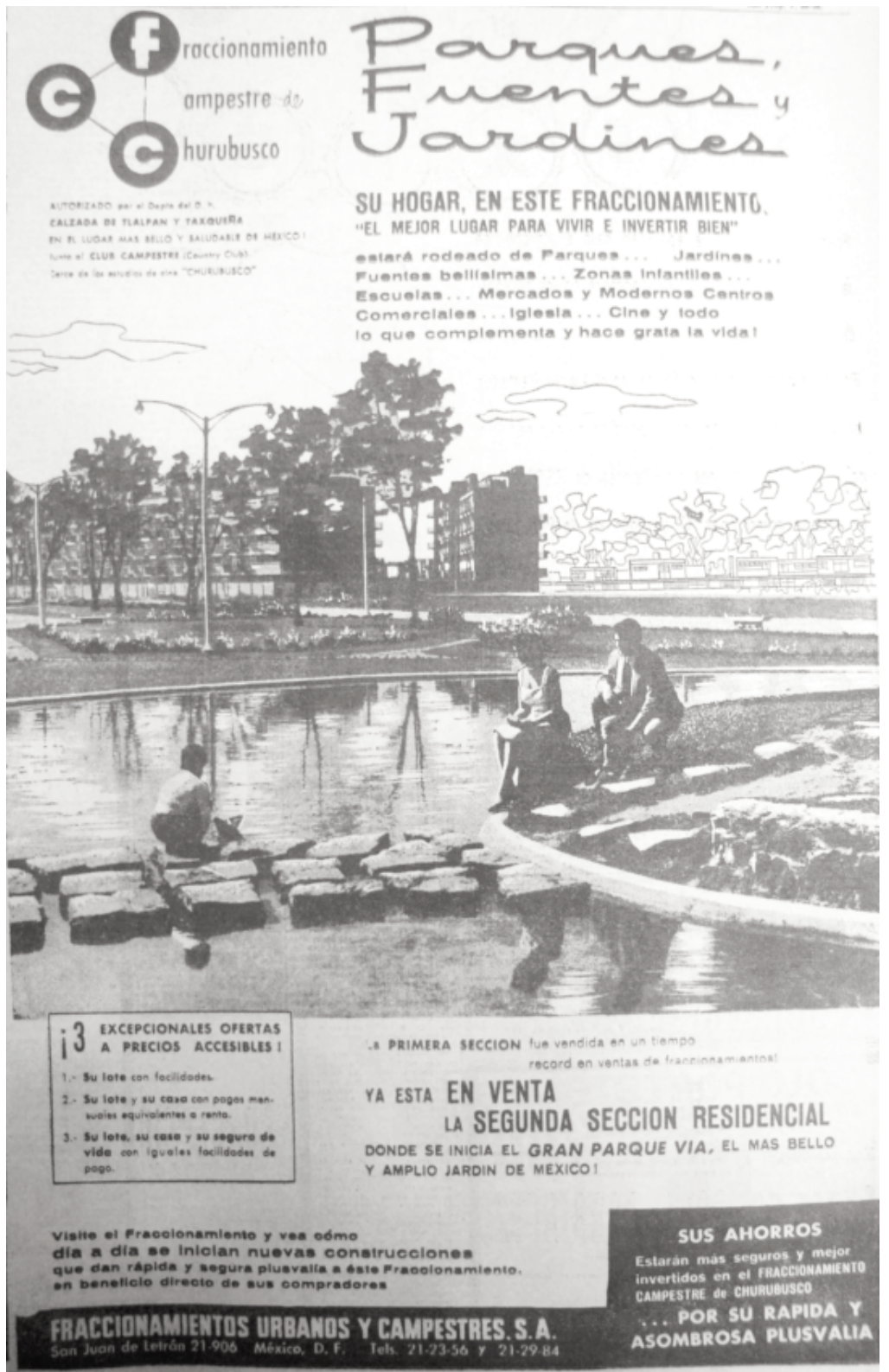

Figura 3. Anuncio Campestre de Churubusco. Fuente: El Universal, 7 de abril de 1957.

\section{()(1) $(3$}




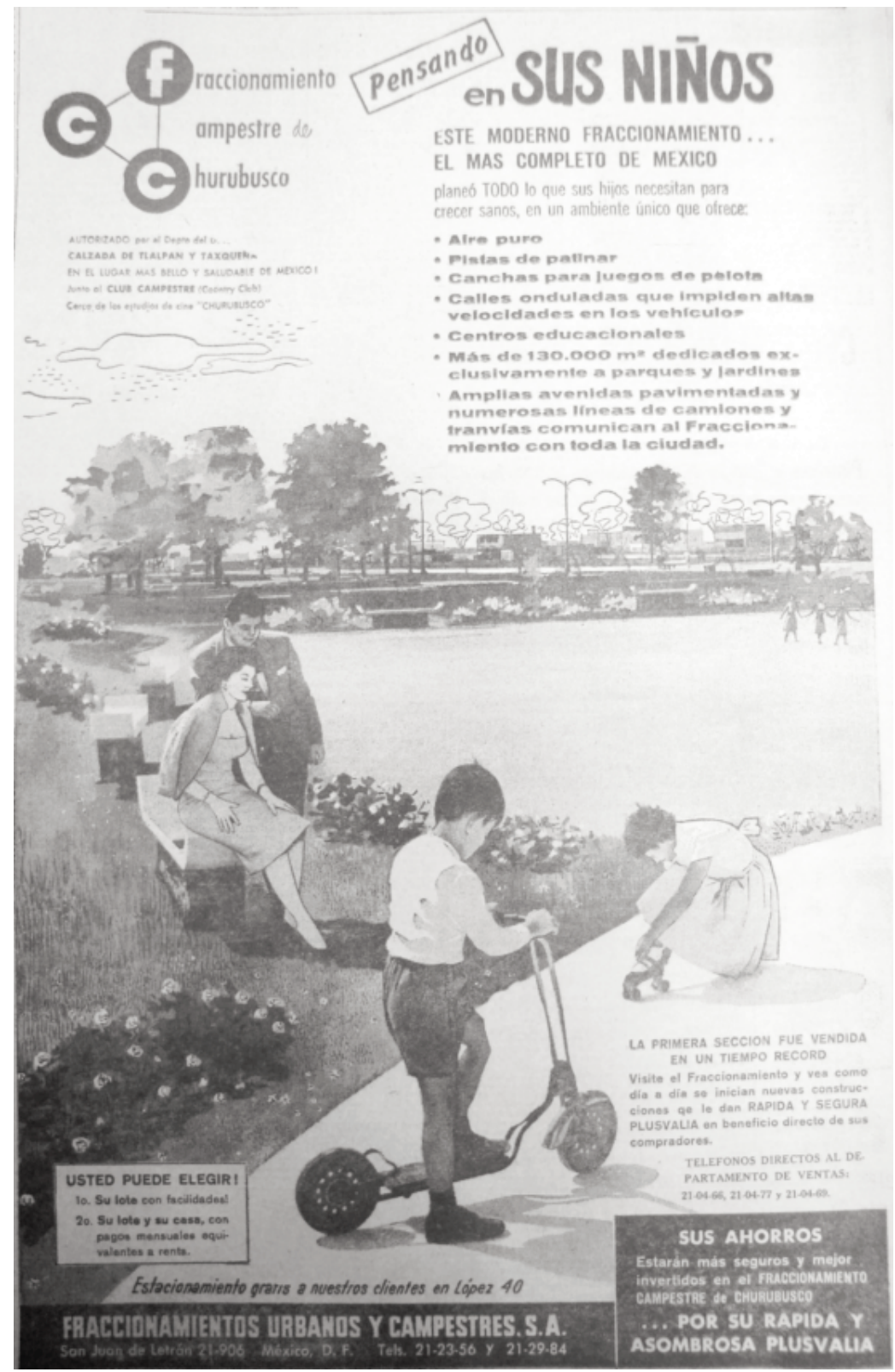

Figura 4. Anuncio Campestre Churubusco. Fuente: El Universal, 21 de abril de 1957.

\section{(ㄷ)(1) (8)}




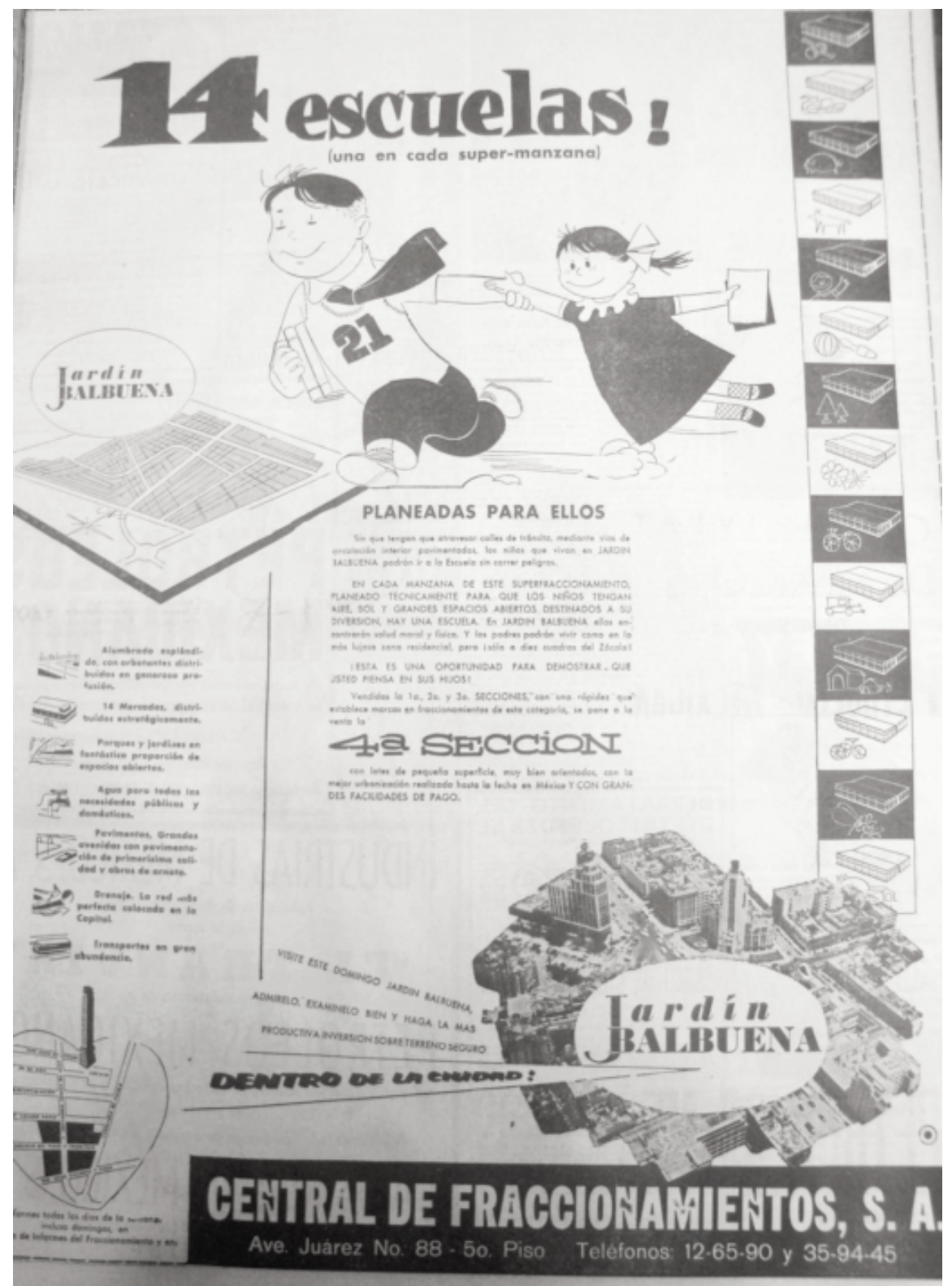

Figura 5. Anuncio Jardín Balbuena. Fuente: Novedades, 18 de marzo de 1956.

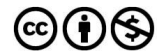


como en la más lujosa zona residencial, pero ¡sólo a diez cuadras del Zócalo!” Esta era una oportunidad para demostrar que los padres pensaban en sus hijos.

De tal forma, los niños desempeñaron un papel relevante en la publicidad inmobiliaria. Aunque muchos anuncios presentaban a la familia nuclear (padre, madre, hijo e hija -casi en ese orden-) decidiendo en conjunto la compra, los niños no parecían tomar decisiones ni dar su opinión. Sin embargo, algunos ejemplos muestran un claro interés en crear emociones también en los niños y convertirlos en sujetos clave de la decisión familiar. En 1965, los publicistas del Residencial Bulevares (véase figura 6), ubicado frente a las torres de Satélite, "ahí donde usted pensó”, prometieron a los consumidores hacer con ellos "la casa de su familia”. El cliente podía escoger entre 20 modelos diferentes de casas con alfombras, teléfonos y gas estacionario. El anuncio invitaba a llevar a los niños a conocer los terrenos "para que se divirtieran" con espectáculos gratuitos del humorista $\mathrm{Hu}-$ go Goodman, genial fonomímico, Javier y sus marionetas, Pirrin y sus payasos, Conchita Solís y sus canciones rancheras y el trío de los hermanos Aguilar. Además, se organizaban concursos para que los niños fueran "pequeños arquitectos" y construyeran una "ciudad infantil" para ganar viajes a Disneylandia. ${ }^{11}$ Finalmente, se invitaba a ver el programa de caricaturas Club Quintito en el canal 5, en el que Genaro Moreno promocionaba todo tipo de productos para niños. Los niños aparecían asociados a la idea de la compra de una casa y en esta actividad se los repre-

\footnotetext{
${ }^{11}$ Anuncio. Novedades, 12 de diciembre de 1965 , p. 13, ciudad de México.
}

senta siempre tranquilos, felices, jugando, seguros, caminando a la escuela, estudiando o durmiendo.

\section{EL HOGAR FELIZ: MUEBLES Y ESPACIOS PARA LA CONVIVENCIA}

La convivencia familiar aparecida en la publicidad da cuenta de la importancia de los espacios y artefactos del interior del hogar. Si la felicidad de la familia podía darse tanto dentro como fuera de la casa, dentro de ella la sala era el espacio privilegiado para la convivencia, distinguible siempre por la presencia de sillones en los que generalmente el padre aparecía sentado leyendo el periódico, escuchando radio y, más cercano a los años sesenta, mirando televisión. El sillón era la representación del lugar de descanso de los padres y sugería una convivencia familiar relajada, en tanto el resto del espacio de la sala de la casa simbolizaba el lugar de juegos infantiles, donde los niños se encontraban delante o detrás de los sillones generalmente acostados o sentados en el piso. Así, según los anuncios, la convivencia ideal podía darse mientras el padre descansaba y hojeaba el diario y los niños jugaban, actores que podían convivir sin prestarse realmente atención el uno al otro, como lo sugiere el discurso visual.

Otro espacio de convivencia dentro del hogar que aparece con frecuencia en los anuncios es la mesa del comedor. Este espacio, donde se comparten los alimentos, es un punto nodal de reunión que provoca que todos los miembros de la familia convivan. En la publicidad casi siempre aparece una convivencia feliz que elude las luchas de los padres para que los hijos coman o discusiones matrimoniales. 


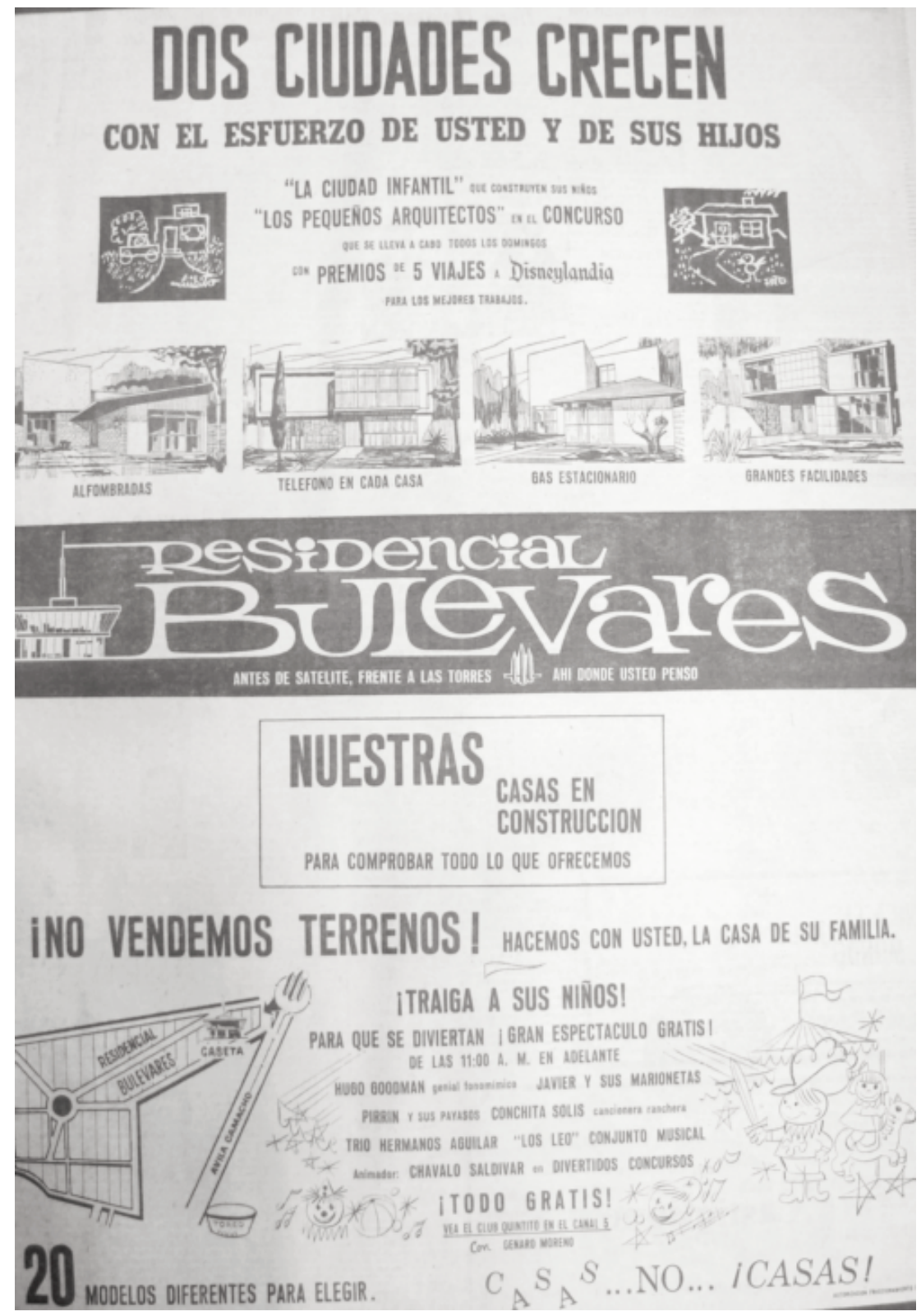

Figura 6. Anuncio Residencial Bulevares. Fuente: Novedades, 12 de diciembre de 1965.

\section{(ㄷ)(1) $(9$}


La hora de la comida, de la merienda o de la cena parece aglutinar un cúmulo de estereotipos familiares: el ocupado hombre de familia, la servicial ama de casa y a los siempre inquietos niños que al fin han hecho una pausa para alimentarse y departir con sus padres.

Finalmente, la cama dentro de las habitaciones aparece como lugar de descanso, placer y felicidad o bien como su antítesis, vinculándose con la preocupación, la enfermedad, la depresión y el dolor. La cama figurará como un mueble en el que los productos ofrecidos, tónicos, pomadas y ungüentos, permiten a los sujetos transitar del dolor a la cura, de la debilidad a la fortaleza, de la enfermedad a la salud, de la tristeza a la felicidad. La cama también aparecerá como un lugar ideal para representar los cuidados maternos.

De tal manera, la casa como espacio inseparable de la vida familiar, en su representación publicitaria, muestra también las transformaciones en la cultura material sucedidas a lo largo de las décadas. Y la función del padre cobra especial relevancia. En la década de 1930 el padre se representa comúnmente sentado en el sillón. En ocasiones aparece leyendo el periódico o fumando, actividades relacionadas con el descanso. Es decir, el papel del padre dentro de la familia parece estar alejado de funciones de cuidado y atención de los hijos o la pareja. Hacia la década de 1960 en cambio, en la publicidad el padre es desplazado del sillón para hacerlo participar directamente en el juego con sus hijos. La imagen del sillón se vuelve innecesaria y dicho objeto tiende a desaparecer de la escena.

El anuncio de Sal de Eno del 16 de abril de 1933 (véase figura 7) en el periódico mexicano Excélsior muestra al padre y a la madre sentados en sus respectivos sillones. El padre lee el periódico mientras su hija, ubicada detrás del sillón, juega a cubrirle los ojos, lo que apunta a un ambiente de felicidad a juzgar por la sonrisa del hombre. En todo caso, es la salud digestiva que asegura el producto la que parece permitir la buena convivencia, pero el sillón, el padre y el periódico parecen conformar una tríada de elementos inseparables en lo que se refiere a la convivencia y el papel del padre dentro del hogar. Esto aparece también en un anuncio de Sal de Uvas Picot del 11 de agosto de 1935 en El Universal (véase figura 8), aunque en este caso el argumento es inverso. Si bien en ambos anuncios es el padre el centro del discurso publicitario, a diferencia de Sal de Eno que muestra un padre tranquilo que convive con la familia, el de Sal de Uvas Picot alude a un padre malhumorado cuya mala eliminación intestinal no permite una convivencia armónica. La felicidad familiar, entonces, se liga también a una buena salud, tanto de padres como de hijos.

La tríada padre-sillón-felicidad vuelve a aparecer en el anuncio de la Compañía Hidroeléctrica del Amacuzac el 5 de enero de 1944 en El Universal (véase figura 9). Dicha compañía muestra a través de la imagen que gracias a su servicio de proveer electricidad, la convivencia puede llevarse a cabo una vez que la luz de día se ha extinguido. Gracias a la electricidad, el padre puede leer bajo la luz de una lámpara mientras fuma, por supuesto sentado en su sillón. La madre puede tostar el pan conectando su tostadora eléctrica en plena sala, pero el riesgo de enredarse con el cable parece ser menos importante que poder ofrecer un té, mientras su hijo juega en el piso, cerca de ellos. En todo caso, lo 


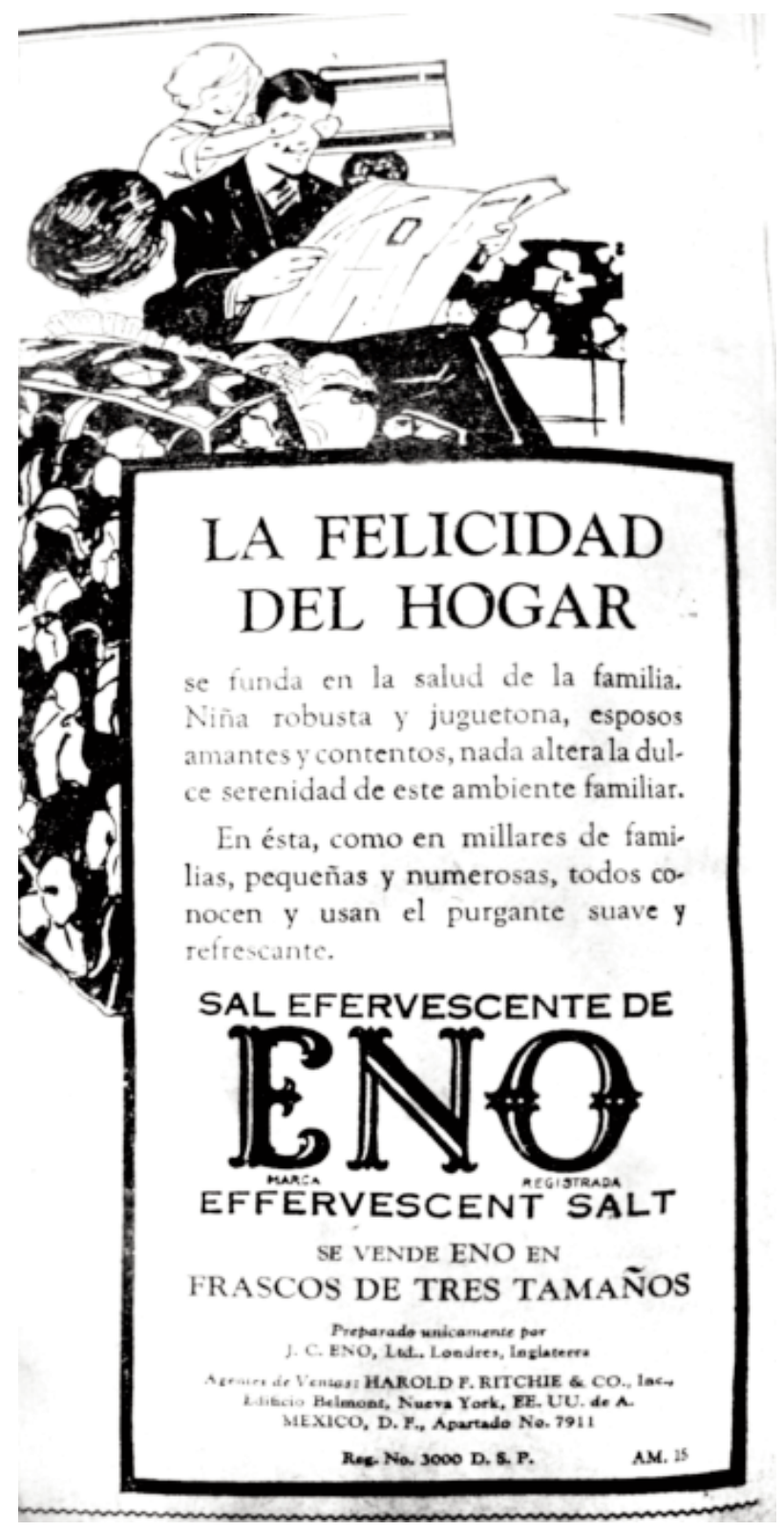

Figura 7. Anuncio Sal de Eno. Fuente: Excélsior, 16 de abril de 1933. 


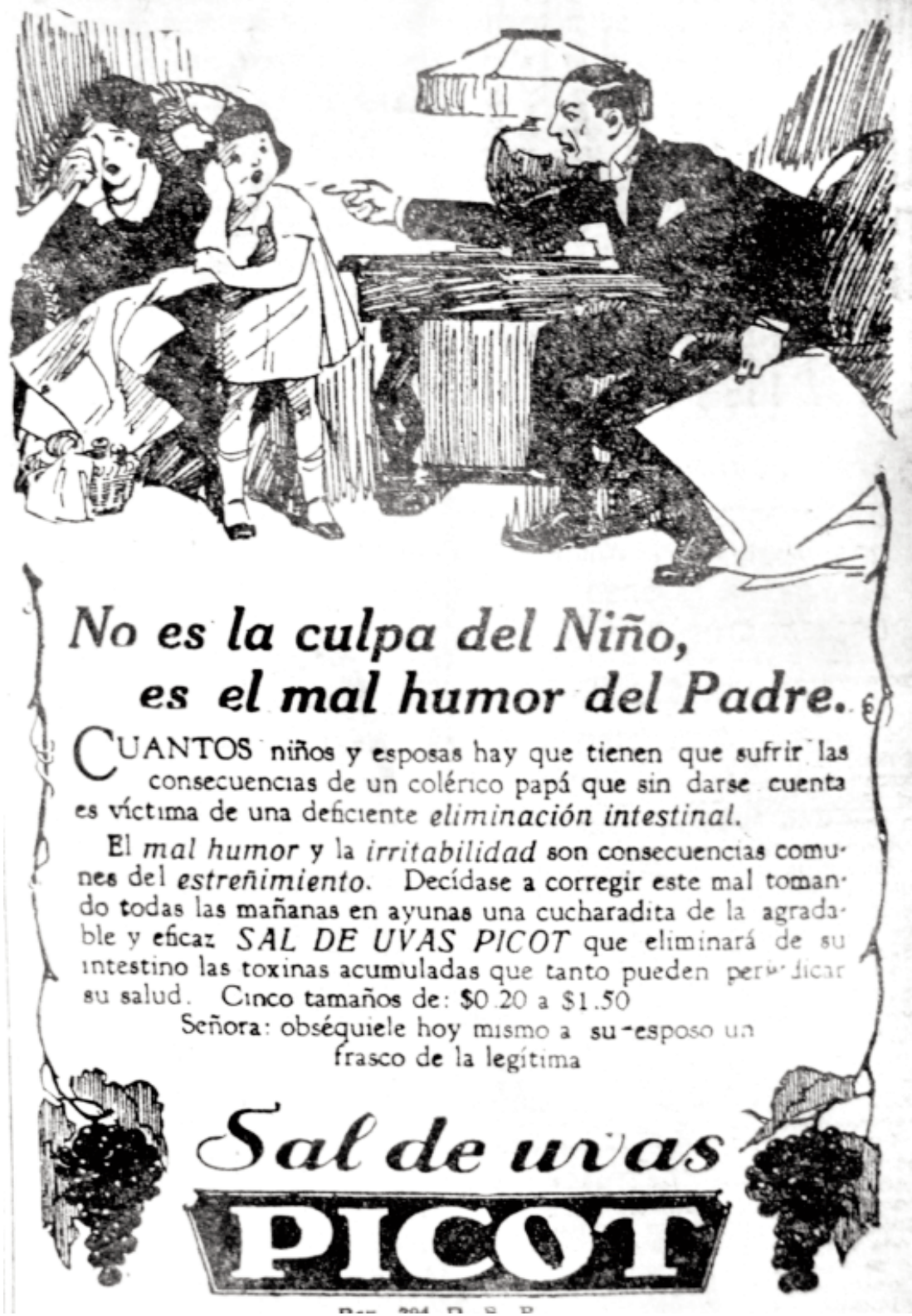

Figura 8. Anuncio Sal de Uvas Picot. Fuente: El Universal, 11 de agosto de 1935. 

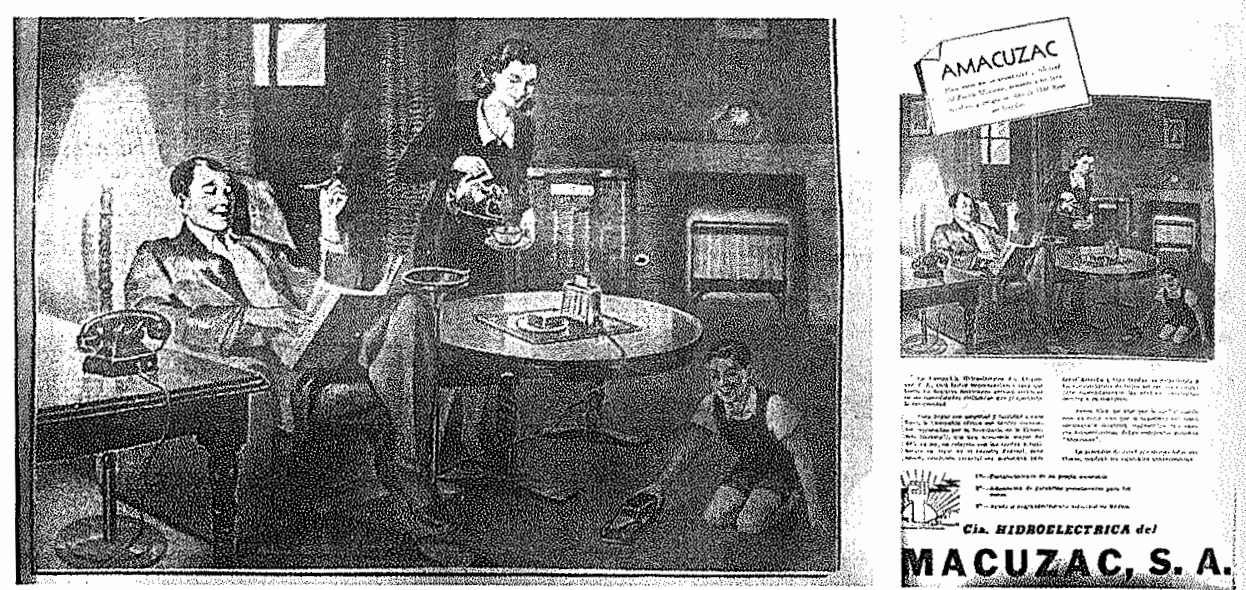

Figura 9. Anuncio Amacuzac. Fuente: El Universal, 5 de enero de 1944.

que este anuncio de luz eléctrica promueve en términos de construcción de discurso visual, es que la feliz convivencia se ha dado gracias a ese servicio, que brinda todas las "comodidades civilizadas" de la electricidad. Se puede ver al fondo de la imagen incluso un aparato de radio, fuente de entretenimiento familiar importante de la época. La publicidad de algunos aparatos de radio también hizo énfasis en que este era una medio de entretenimiento que promovía la convivencia familiar (en este periodo se pueden encontrar varios anuncios que muestran a la familia junto con el aparato de radio, que era notoriamente grande).

En los años cincuenta y cerca de la década de 1960 aparecen algunas variantes en torno a la representación del padre y la convivencia familiar. El anuncio de "El regalo ideal" del 10 de diciembre de 1953 de la marca Kodak (véase figura 10) muestra a una familia junta, en temporada navideña, cerca de una chimenea y con juguetes en el suelo. La madre observa la escena y decide conservarla gracias a su cámara Kodak, atesorando este momento de convivencia y felicidad infantil para siempre. La particularidad del anuncio es que no muestra ningún sillón, porque su propósito es dar cuenta de que la representación del padre y las relaciones que establece con sus hijos han variado considerablemente. El padre aparece ahora en el piso jugando con su hijo. El caso es el mismo en el anuncio que aparece tres años antes en 1950 en El Universal para Banco de América, en el cual se muestra a una familia. La madre está sentada en un sillón sosteniendo una niña, y el padre se encuentra jugando otra vez en el piso con su hijo.

En un anuncio de Pepsi del 10 de mayo de 1958 en El Universal se puede observar también la insistente presencia del sillón, pero ahora la madre es la única que aparece sentada en él; los niños y el padre se encuentran frente y detrás de él respectivamente. Si se admite que en estos anun- 

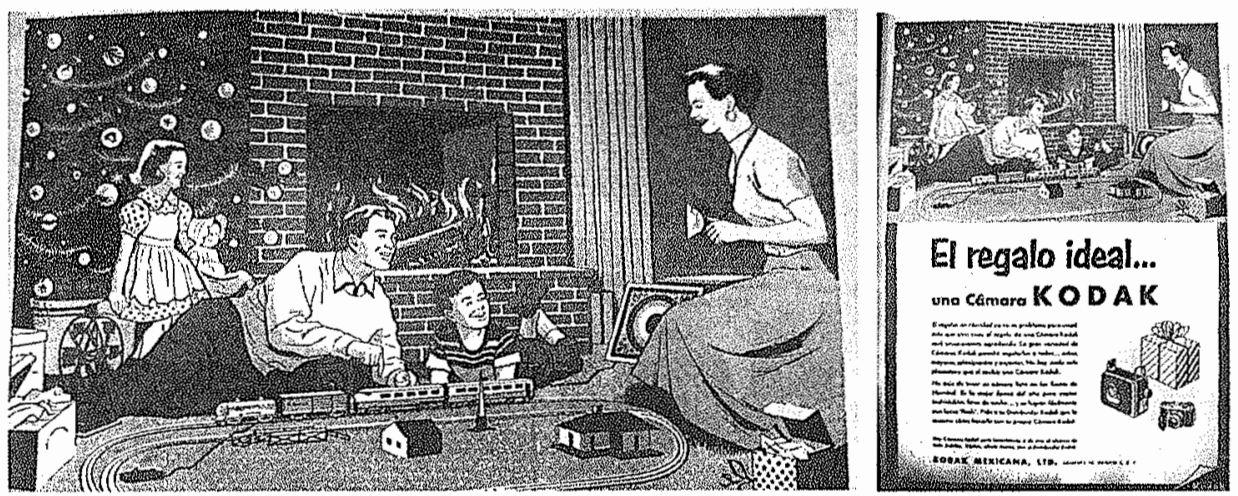

Figura 10. Anuncio Kodak. Fuente: El Universal, 10 de diciembre de 1953.

cios se representa una participación más activa por parte del padre en cuanto a la convivencia se refiere, entonces esta transformación puede indicar no sólo cambios a nivel publicitario sino también a nivel de la vida cotidiana en las familias mexicanas.

Como hemos señalado, otro de los espacios de convivencia al interior de la casa subrayado por la publicidad, que aludió a la felicidad como gancho para la compra de los productos, fue la mesa del comedor, ya sea a la hora del desayuno, la comida o la cena. Sin embargo, el comedor, aunque representa momentos de felicidad para los niños, no los relaciona con el descanso o el juego como sí lo hace la sala. Aunque haya intercambio de sonrisas entre los personajes, este espacio parece estar destinado a compartir el alimento, a conversar, e imponer cierto orden disciplinario sobre los hijos. En la publicidad siempre reina la armonía a la hora de comer. La mesa que reúne a la familia sirve también como espacio simbólico para reforzar los papeles femeninos y recordar, a veces en tono de alabanza, las funciones domésticas de la mujer: es la madre-esposa la que prepara, hornea, guisa y sirve la comida, y eso parece ser parte esencial del aseguramiento de la estabilidad familiar. ${ }^{12}$ Como lo señalaba el médico mexicano Alfredo Ramos Espinosa (1952) en su conocido libro de puericultura titulado El cuidado del niño, la felicidad infantil se vinculaba también con ciertos hábitos, entre los cuales se anotaba que el niño habría de "sentarse a la mesa con alegría mirando en cada alimento recuerdos amables de la vida familiar" (p. 18).

Pero en el comedor también operarán transformaciones a lo largo de las décadas que estudiamos. Anahí Ballent (1996) ha documentado cómo para la década de los años cincuenta el comedor, lugar de encuentro tradicional de la familia, era

${ }^{12}$ Anuncio. El Universal, 12 de marzo de 1956, p. 7, ciudad de México; Anuncio. La Prensa, 1 de diciembre de 1953 , p. 23, ciudad de México; Anuncio. El Universal Gráfico, 1 de febrero de 1943, p. 5, ciudad de México. 
también un lugar simbólico de construcción de la paternidad. La revista Femenil, según esta autora, señalaba que ya no había espacio para asuntos terribles, tonos sombríos, tristeza o padres barbados, ahora los padres no podían "estar excesivamente serios y graves frente a sus hijos, al compartir el pan sobre sencillos y alegres manteles. No caben allí escenas de melodrama, la vida ríe, y si no ríe, forzoso es hacer que ría" (pp. 53-74). En ese sentido, aunque los anuncios en los que la mesa del comedor se convierte en un elemento central no denotan cambios reiterados que indiquen alguna tendencia, un anuncio publicitario de la cámara Kodak en el año de 1958, en El Universal, propone una escena valiosa para filmar: el momento en el que el padre da de comer en la boca a su bebé. Este es un cambio significativo, ya que por lo general los anuncios responsabilizaban a las madres de esta labor, y el hecho de que un padre lo haga, al menos en el discurso publicitario, construye una escena digna de filmarse y conservarse para siempre.

El hogar publicitario aparece segmentado en múltiples espacios: si el comedor y la sala son generalmente lugares de convivencia generadores de felicidad, a estos se les contraponen espacios más íntimos, como el baño y la habitación. En especial esta última, que aparece como un ámbito generador de emociones opuestas a la felicidad: la enfermedad, el cansancio, la angustia, representadas generalmente por sujetos que convalecen en la cama o bien están sentados en ella, sufriendo lejos de la mirada de familiares y visitantes. Los publicistas tenían claro que existía una serie de recursos que podían utilizarse para llamar la atención. Uno de ellos era lo que se denominaba en 1954 las "sugestiones negativas" (Casas, 1954, p., 168), que demostraban lo que podía perderse, suscitando el temor, las enfermedades, el porvenir dudoso, el miedo. En ese sentido, un mueble podía asociarse con el bienestar y la comodidad, otro con lo contrario.

De tal forma, la publicidad indica que la enfermedad de un miembro de la familia o el sufrimiento del hombre deben expresarse o contenerse en el espacio de la habitación. A diferencia del comedor o de la sala, la habitación permanece per se lejos del ojo público ya que es el lugar de las prácticas más íntimas incluso en el orden de lo familiar. El 2 de marzo de 1944, en el periódico La Prensa se publicó un anuncio en forma de historieta en torno al Linimento de Sloan, un fármaco que servía para el alivio del lumbago, ciática, torceduras y calambres musculares (véase figura 11). Aunque el género de historietas nunca llegó a tener una presencia tan numerosa en la prensa como la tuvo el formato tradicional publicitario, resulta importante como objeto de estudio por distintas razones, entre ellas su aspecto secuencial. En el anuncio citado se puede ver la secuencia del estado de una persona previo a la enfermedad, durante y después de la misma, y en ese proceso aparece la cama como la representación de la enfermedad, de la inmovilidad, de la no felicidad y de la dependencia de otro integrante de la familia.

La cama aparece así no sólo como signo principal de la enfermedad en el cuidado de niños, sino también como lugar de reposo para pasar los efectos de los abusos del alcohol, aspectos visibles a través de anuncios como el de Mistol del 25 de enero de 1942 en Excélsior (véase figura 12), en el que una madre se preocupa por el resfrío de su niña, o el de Sal de Uvas 

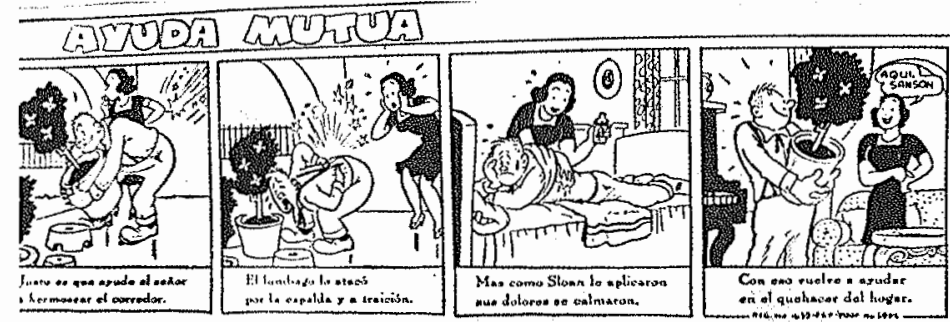

Figura 11. Anuncio Linimento de Sloan. Fuente: La Prensa, 2 de marzo de 1944.
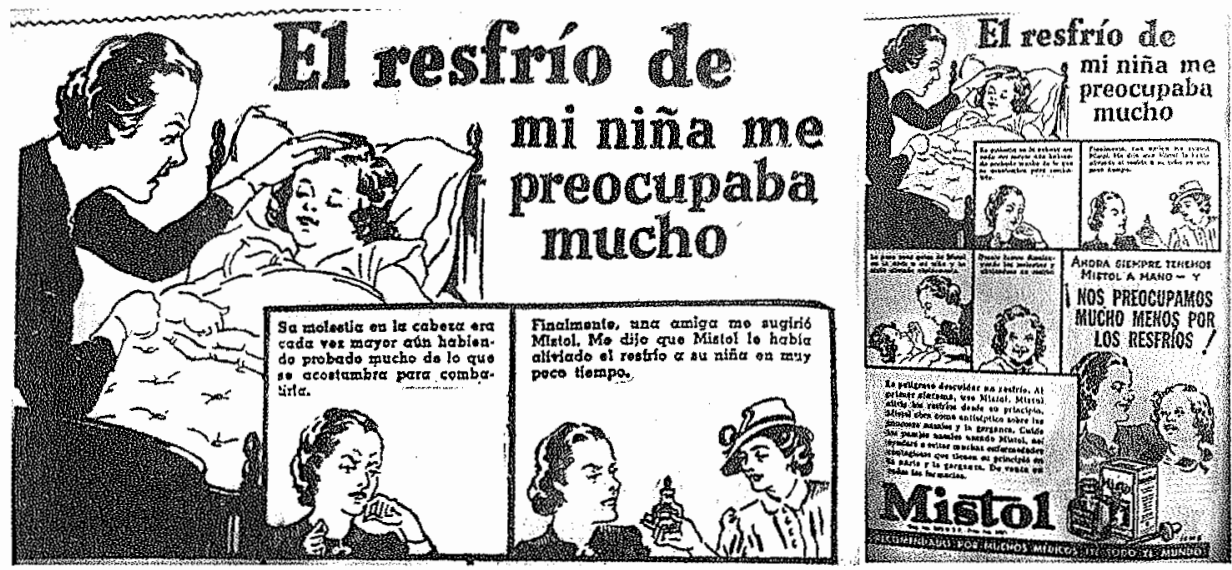

Figura 12. Anuncio Mistol. Fuente: Excélsior, 25 de enero de 1942.

Picot del 13 de julio de 1936 (véase figura 13) en el que se muestra a un padre llevándose la mano a la frente mientras, sentado en la cama, se quita los zapatos y recibe los cuidados de su pequeña hija, quien le lleva el remedio.

Si bien tanto el sillón como la cama son muebles destinados al reposo, estos son dotados de distintos significados que les otorgan matices diferenciados. El sillón se convierte en espacio de descanso pero de convivencia relajada que permite la interacción entre los integrantes de la familia. La cama, por el contrario, si bien permite el reposo, de alguna manera inmoviliza, aísla $y$ hace dependiente a la persona que se encuentra en ella. Aunque la cama se usa como objeto para representar el placer del descanso provocado por un colchón o unas sábanas, generalmente no hay ahí convivencia familiar en términos de felicidad sino más bien de cuidados al enfermo. En un anuncio de $E l$ Universal (véase figura 14) se muestra claramente que el hombre es el que sufre de manera solitaria sobre el porvenir de su familia, acostado en 

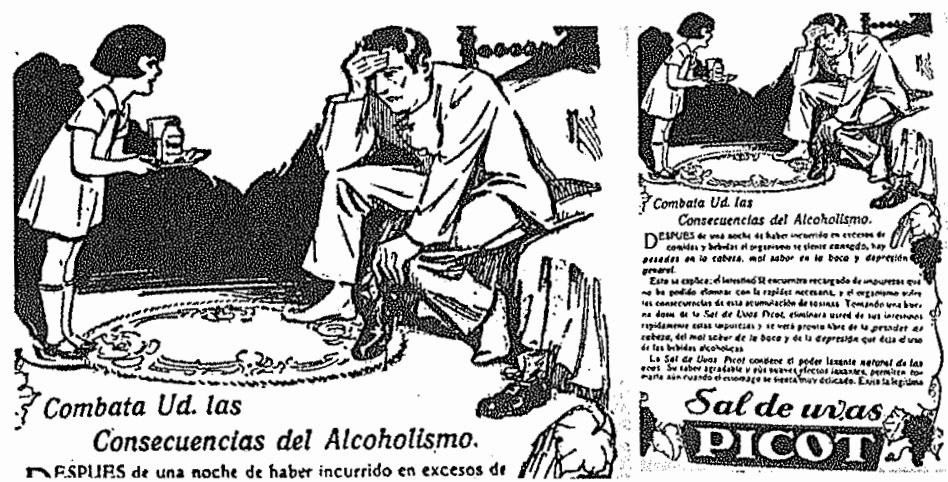

Figura 13. Anuncio Sal de Uvas Picot. Excélsior, 13 de julio de 1936.
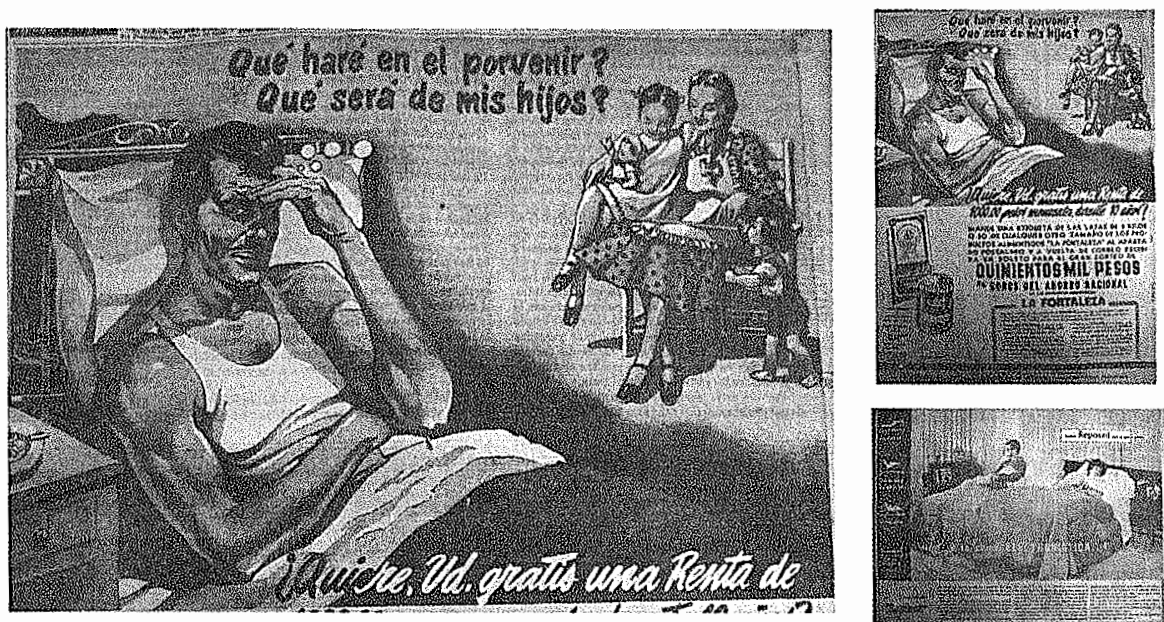

Figura 14. Anuncio Bonos del Ahorro Nacional. Fuente: El Universal, 18 de octubre de 1951.

su cama, mientras aquella se representa feliz en un sillón en el que la madre lee un libro a sus pequeños hijos, pero no dentro de la habitación matrimonial. En la década de los años sesenta se encuentran paulatinamente cada vez más anuncios que asocian la habitación y elementos de la convivencia familiar con la felicidad, aunque también promuevan actividades individuales. En 1965, un anuncio de una cama electromática (véase figura 15) dará cuenta de la interacción de un matrimonio en la habitación. La imagen sugiere que a pesar de que marido y mujer están en la misma habitación, su actividad no es de convivencia, pues el anuncio promueve 


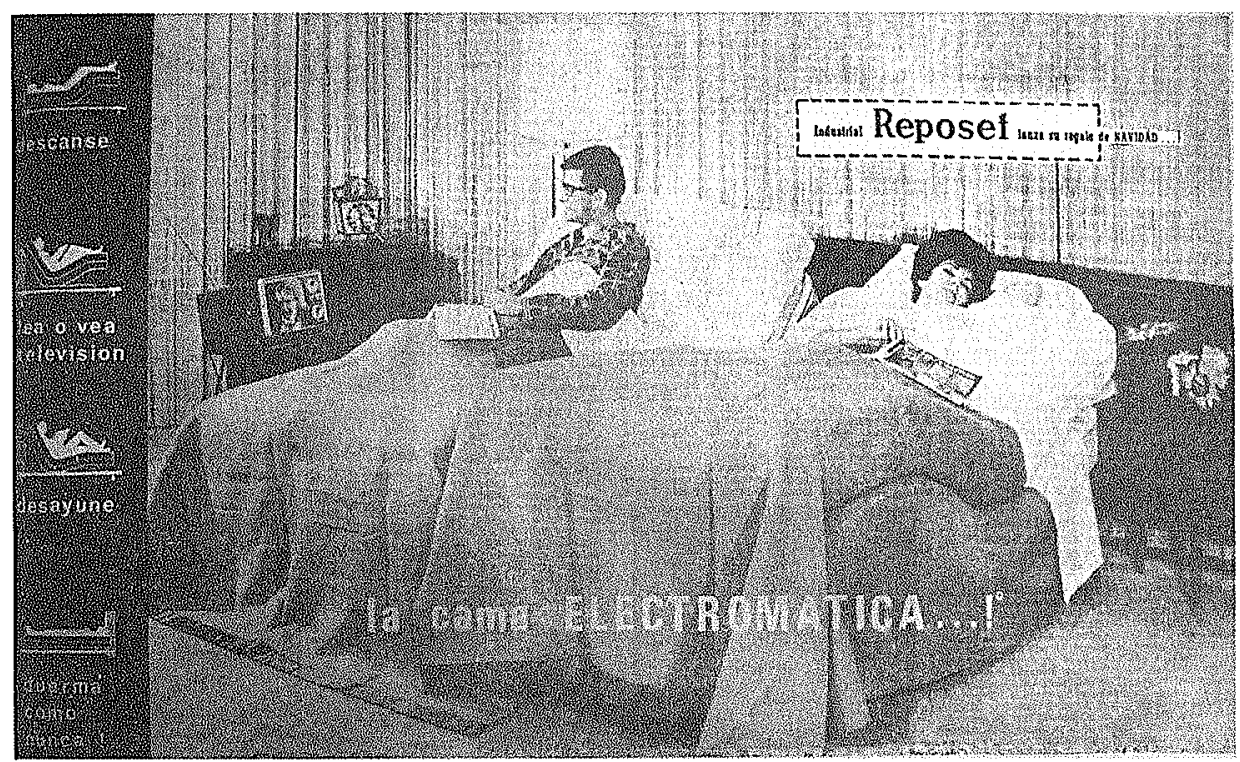

Figura 15. Anuncio Cama Electromática. Fuente: Novedades, 26 de diciembre de 1965.

actividades individuales. La individualidad es enfatizada por el anuncio en tanto ambos personajes se encuentran mirando en dirección opuesta. "Descanse, desayune y duerma como nunca" son los beneficios que se pueden obtener gracias a la cama electromática, la cual presenta el respaldo del lado del marido en una posición distinta al de la mujer, así como posiciones distintas de la parte dispuesta para los pies. La cama electromática, pues, promueve el buen descanso a partir de la individualidad de la persona. La convivencia aparece incluso individualizando una actividad que podría ser compartida, como mirar la televisión, ya que el anuncio propone que el marido pueda hacer esta actividad mediante un pequeño aparato colocado a un costado de la cama mientras su mujer descansa.

\section{LA ESCENA CAMPESTRE}

La publicidad alude a otros espacios de convivencia familiar que se encuentran fuera de la casa. Y es el espacio campestre el que aparece como espacio idealizado de la felicidad, contrapuesto a las vicisitudes de la ciudad moderna, el urbanismo y los ruidosos medios de transporte. El ambiente campestre, como espacio de convivencia familiar, es distinguible siempre por escenas arboladas que suponen socializar al aire libre. La convivencia al ras del pasto es siempre una constante y los anuncios que apelan al ámbito campestre abundan en propuestas inmobiliarias, nuevos automóviles y consumo de alimentos. Para salir de día de campo y contar con todo lo necesario, el objeto que parece haber desempeñado un papel importante a nivel 
publicitario fue la caja, de madera o de cartón. Los anuncios de la cerveza Corona del 15 de julio de 1934 en El Universal y de Orange Crush el 4 de julio de 1936 en el Excélsior, muestran la presencia de cajas en la escena de convivencia campestre de la familia. También existen otros elementos como el mantel sobre el suelo (que pareciera tener la función de sustituir a la mesa), los alimentos, los platos y los cubiertos. La convivencia campestre que gira en torno a la comida se asemeja a la que se sugiere al interior de la casa a través de la mesa del comedor. En el mantel cae todo el peso de la escenificación del espacio de convivencia, pues es a su alrededor o sobre este que la convivencia sucede. Gracias al mantel, la mesa, la convivencia y el hogar han encontrado un lugar fuera de casa.

El anuncio de Cervecería Cuauhtémoc del 1 de abril de 1933 en el Excélsior (véase figura 16), muestra un énfasis importante en la caja. Dos felices niños caminan sobre el pasto cargando una pesada caja de cartón con diez botellas grandes de cerveza, diez vasos individuales, diez servilletas y un abridor, mientras sus padres, que han dejado atrás el auto familiar, caminan sonrientes detrás de ellos. Dos elementos son relevantes: el día de campo y la caja con diez cervezas. El día de campo, escena reiterada en varios anuncios del periodo 1930-1970, se vuelve notable no sólo porque da cuenta de ciertas costumbres de la época, sino porque lo "campestre" se convierte en un espacio ideal de convivencia como medio para llegar a la felicidad. Este espacio alejado de casa, pero también de la ciudad, reivindica la naturaleza como un espacio ideal de unión entre padres e hijos, incluso como un espacio al que hay que aspirar. La caja con diez cervezas se con- vierte en otro elemento importante. Viene lista para el día de campo, las cervezas ya no tienen que empacarse para el camino sino que están protegidas, el consumidor no tiene que llevar vasos, como se ve en los otros anuncios, pues la caja incluye diez, así como servilletas y destapador. Todo lo necesario para un día de campo. La familia ha entrado en la cultura del ready-made, es decir, del consumo "listo para llevar". ${ }^{13}$ Nótese que aun así, en el anuncio el padre trae otra caja cargando. Es decir, aún y cuando la caja de cervezas contempla lo necesario para un día de campo, otra caja aparece como elemento ideal para la convivencia fuera de casa, resaltando su importancia en la construcción de la transportación del hogar fuera de este.

En el caso de productos como la cerveza, el anuncio de Corona y Negra Modelo en 1934 (véase figura 17) elaborado por el dibujante mexicano Salvador Patiño, mostró nuevamente a una familia nuclear pasando un día de campo en un lugar arbolado. Es significativo que en un momento de campañas antialcohólicas y de la convicción de que los niños no debían tomar alcohol, los anuncios enfaticen su papel activo en la promoción del consumo de cerveza. Si en el anuncio anterior cargan la caja con las bebidas, en este se disputan las corcholatas. Así, el discurso publicitario sugiere que si se tomaba cerveza era también para hacer felices a los hijos, pues cada corcholata tenía un valor de cinco centavos que ellos podían utilizar.

${ }^{13}$ Las diez cervezas con sus diez vasos representan también la cantidad de gente, es una caja para compartir en familia o con amigos, aspecto que promueve la convivencia, por lo tanto, cervecería Cuauhtémoc fomenta la convivencia, misma que implica felicidad. 


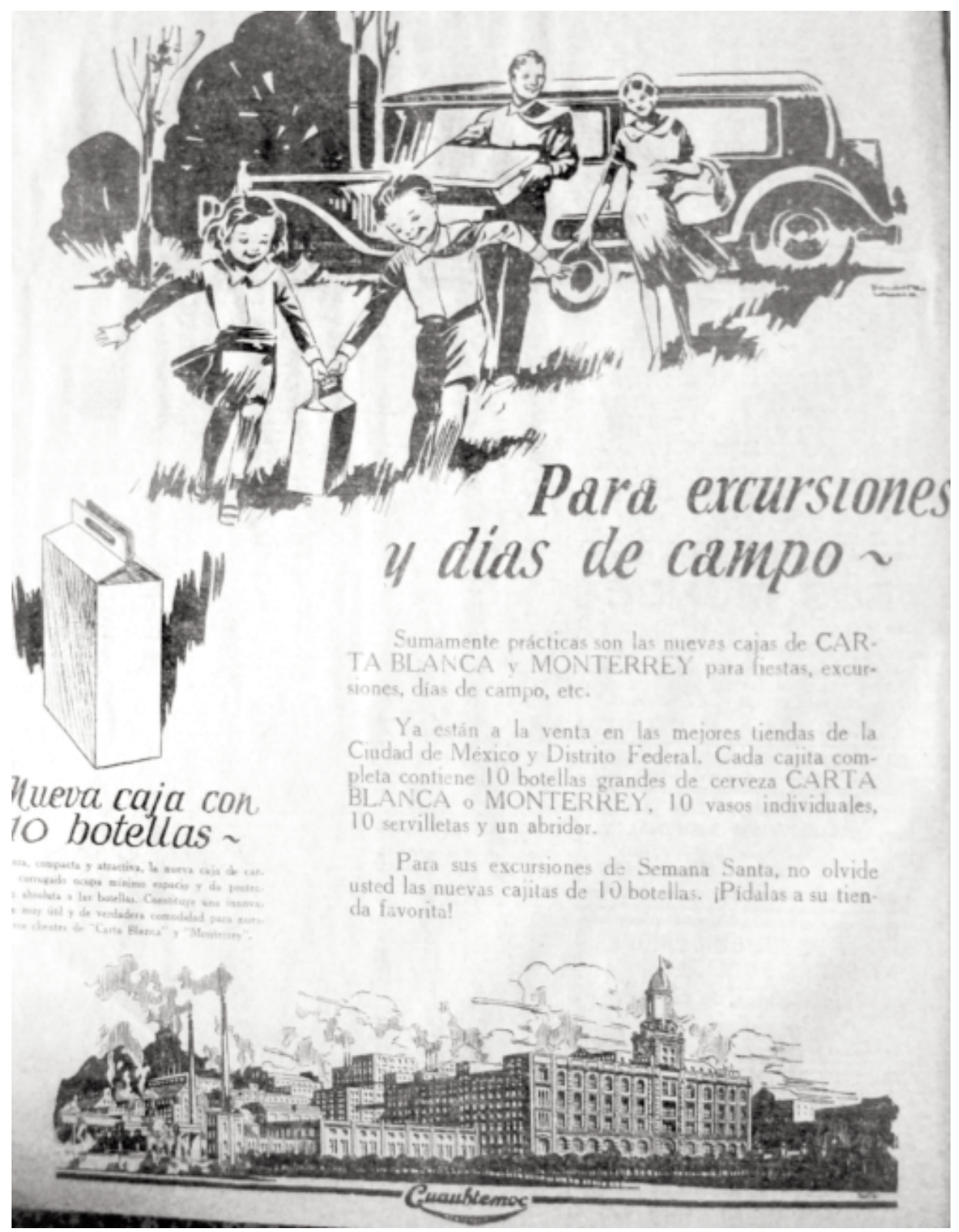

Figura 16. Anuncio Cervecería Cuauhtémoc. Fuente: Excélsior, 1 de abril de 1933.

\section{(ㄷ)(1) $(8$}




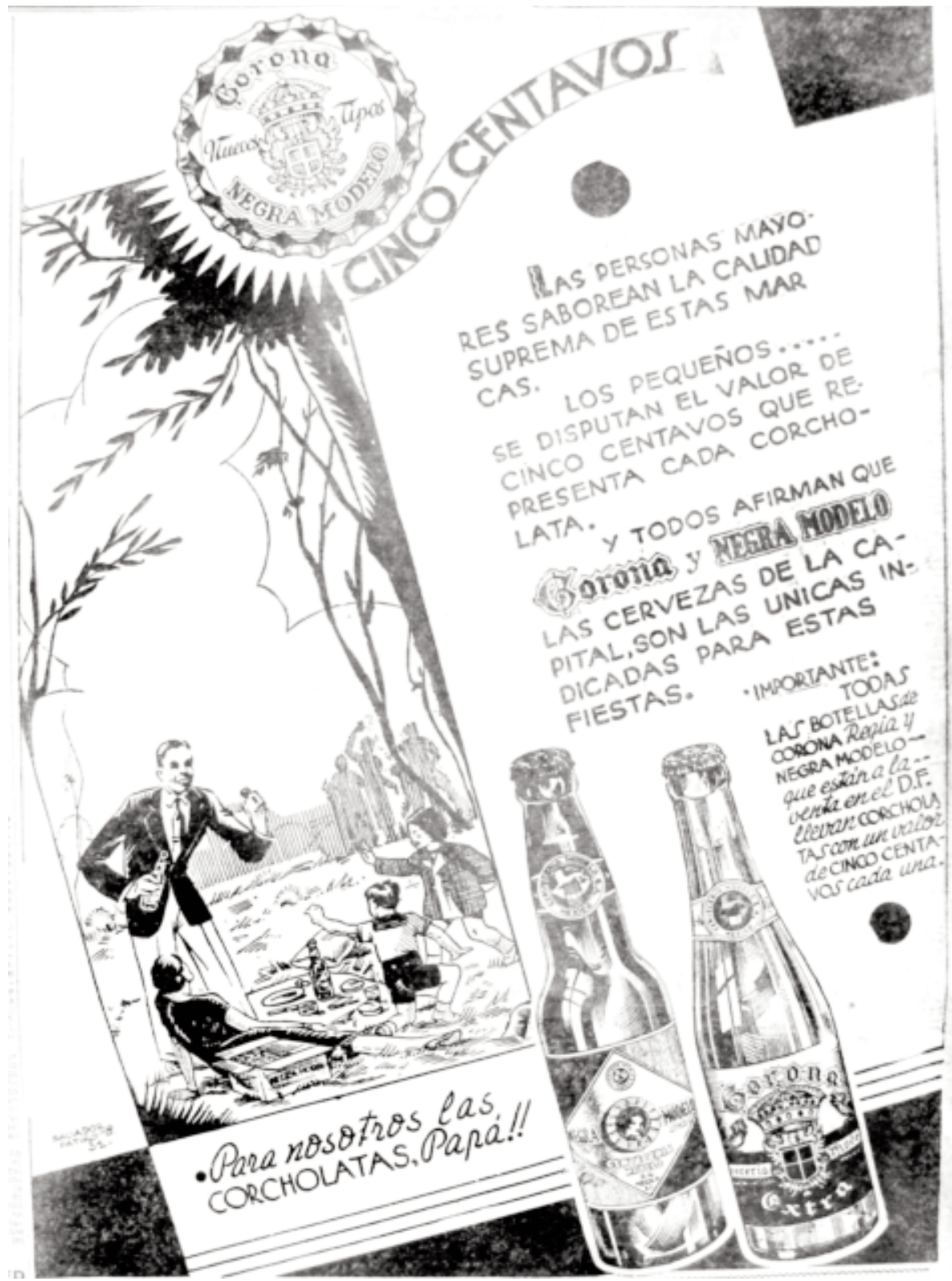

Figura 17. Anuncio Corona y Negra Modelo. Fuente: El Universal, 15 de julio de 1934.

\section{(c) (1)}


El crecimiento exponencial de los automóviles entre las clases medias y altas en estas décadas permitió que lo campestre fuera más accesible y ocupara un lugar fundamental en el imaginario, las áreas verdes, las referencias a los paisajes campestres, el nombre de algunas de las principales colonias de la ciudad de México (Las Lomas, El Pedregal, Country Club, Campestre Churubusco, Del Valle), la necesidad de aire fresco y la propia arquitectura funcionalista privilegiaron los espacios verdes. La posesión de una propiedad en zonas específicas de la ciudad o la convivencia en espacios rodeados de pájaros y árboles parecieron asegurar la felicidad y la unión familiar, la tranquilidad, la salud y la emoción de que a pesar del predominio de las máquinas el individuo podía estar conectado con la naturaleza.

\section{CONSIDERACIONES FINALES}

La felicidad publicitaria en estos años se ligó con el concepto de convivencia familiar, mismo que se imbricó con la compra de productos tan variados como juguetes, alimentos, automóviles, casas o terrenos. Lo que la publicidad a través de su discurso visual y textual pareció enfatizar fue que los niños serían felices en proporción al vínculo con su núcleo familiar, a las posibilidades de compartir actividades en común y a su nexo con los productos ofrecidos. Los padres publicitarios, especialmente las madres, aparecieron siempre alrededor de los niños en escenarios que por lo general reflejaban ya fuera el interior del hogar (sala, comedor, habitación) o espacios abiertos (campo, parques, jardines) en los que predominaba una convivencia afectiva, padres sonrientes y felices de tener a los hijos cerca. Posiblemente de todos estos sujetos, fue la figura del padre la que observó más cambios a lo largo del periodo 1930-1970, pasando de un padre alejado de los hijos que lee el periódico sentado en un sillón a un padre que se recuesta en el piso para estar al nivel de los pequeños y compartir juegos y juguetes con ellos. La madre va pasando, aunque de forma muy paulatina, de su acción limitada exclusivamente al ámbito doméstico a ser una figura cada vez más vinculada con las actividades fuera del hogar. Por otro lado, frente al modelo e ideal de convivencia familiar ligado al consumo como sinónimo de la felicidad, aparecen como un recurso publicitario eventos que obstaculizan esta emoción: la ausencia, el mal humor o las enfermedades del padre debido a la falta de vitaminas, o las dolencias de la madre debido a jaquecas o molestias "propias del organismo femenino" (véase figura 18). Los productos ofrecidos como analgésicos, vitaminas, y seguros de vida prometían eso mismo, garantizar el mantenimiento de una convivencia feliz.

El hogar como espacio por antonomasia de la convivencia familiar se reiteró en múltiples anuncios, la familia reunida en torno a la mesa a la hora de la comida, en la sala de la casa o a la hora de la merienda fueron recursos utilizados con frecuencia como elementos que construyeron un discurso visual sobre la idea de felicidad en México. La convivencia en la mesa mostró a la familia completa en ocasiones cotidianas o especiales. La representación de la felicidad se da en la imagen a través de los personajes que sonríen unos a otros y en este ambiente de convivencia el producto o marca es un elemento más: la campaña de Kellogg's de la familia sonriente (véase figura 19) en el desayuno 


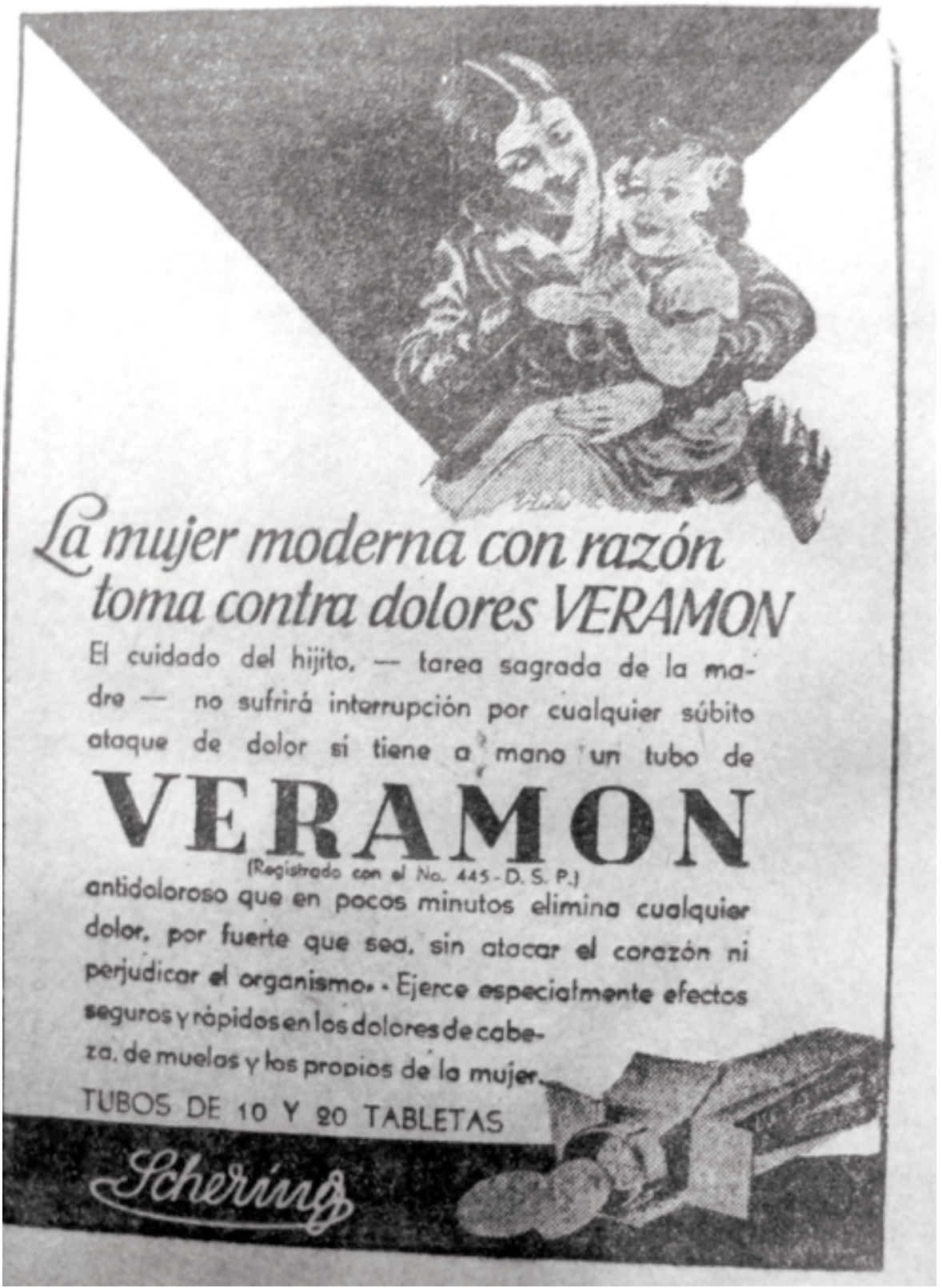

Figura 18. Anuncio Veramon. Fuente: El Universal, 14 de abril de 1932.

\section{(ㅇ)(1)(8)}




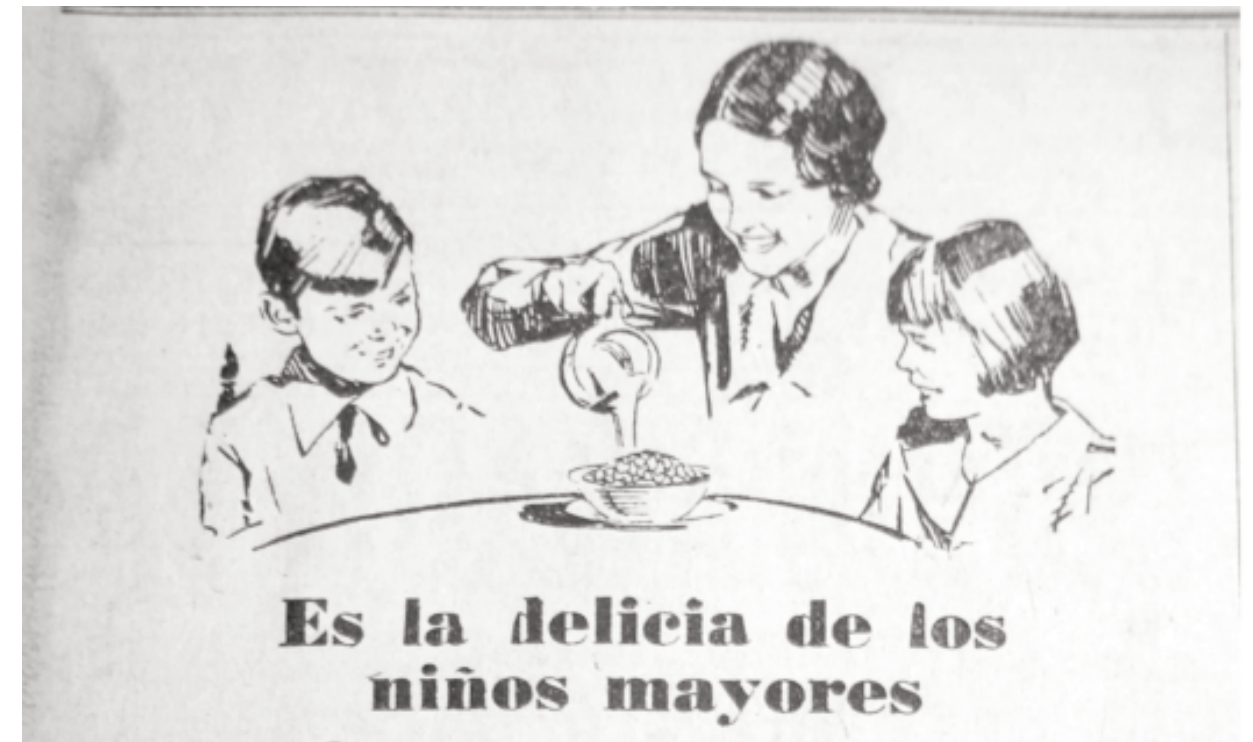

$\mathrm{M}$

ILLLONES derbuenas" madres bendicen el Kellogg's Corn Flakes, cuyo sabor invita irresistiblementet a, los 'muchachos 'a comer :..' siendo?además tan'nutritivo ... crujiente $5^{4} y^{\prime}$ fácilide digerir. Sirvalo

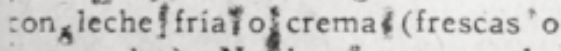
ivaporadas).. No, hay que - cocerlo. Fuede ponérsele, fruta 0 miel para variar,"
Insustituible cereal para el desayuno, pero es también un bocado ideal como merienda o postre. Apetece por igual a jovenes y viejos.

Exija Kellogg's, el "corn flakes" legítimo. de sabor inimitable. Siempre fresco como salido del horno. De venta en todas las tiendas de comestibles en su paquete verde y rojo.
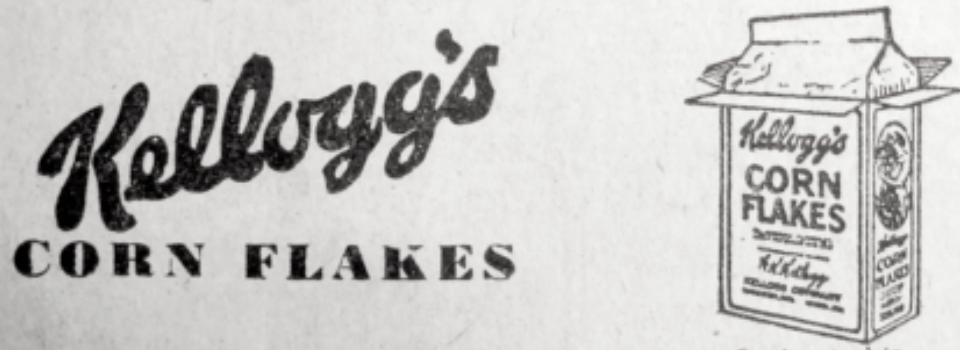

res.

Creadorea cambuin

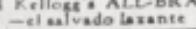

Figura 19. Anuncio Kellogg's. Fuente: El Universal, 2 de marzo de 1938. 
mostrará estos atributos por muchos años. En otras palabras, en ese ambiente feliz el producto coexiste con otros elementos que construyen la convivencia, como la mesa, la proximidad de los personajes, sus sonrisas y el resto de los alimentos presentes en la escena.

Resalta en los anuncios la poca alusión a sectores obreros o campesinos y en cambio la repetición de la representación de escenas familiares que aluden a las clases medias y altas. Esto se explica porque las familias de los sectores populares, lastimadas por la crisis económica y luego marginadas de los efectos más benéficos del milagro mexicano y del desarrollo estabilizador, difícilmente pudieron ajustarse a las pretensiones modernizadoras y consumistas que se impulsaron desde el gobierno y la iniciativa privada. Además, a diferencia de la construcción visual nacionalista propia de los años veinte y treinta, que recuperó a los sectores populares como el "nosotros nacional", los años cincuenta y sesenta reforzaron un discurso que buscaba presentar al mexicano promedio como un hombre o mujer de clase media. De tal modo, la publicidad gráfica en la prensa de estos años reflejó no sólo las nuevas preocupaciones sobre la forma de tratar a los niños y hacer de ellos sujetos felices, sino también las transformaciones en la paternidad, la maternidad y las formas del habitar doméstico. Pero, fundamentalmente, la publicidad contribuyó a construir un imaginario visual sobre lo que significaba una emoción. Parece un lugar común señalar que las emociones humanas son también construcciones sociales y culturales, es decir que responden a un tiempo y espacio determinados, pero el análisis publicitario que hemos presentado en las líneas anteriores parece reafirmar que una producción cultural, en este caso la publicidad gráfica, produjo contextos educativos informales donde niños, mujeres, y hombres pudieron aprender a identificar emociones, sensibilidades y deseos.

\section{LISTA DE REFERENCIAS}

-Ballent, A. (1996). La publicidad de los ámbitos de la vida privada. Representaciones de la modernización del hogar en la prensa de los años cuarenta y cincuenta en México. Alteridades, 6(11), 53-74.

-Brites, O. (2000). Infancia, higiene e saude na propaganda (usos e abusos nos anos 30 a 50). Revista Brasileira De Historia, 20(39), 249-278.

-Bunker, S. y Macías González, V. M. (2011). Consumption and Material Culture in the Twentieth Century. En W. H. Beezley (ed.), A Companion to Mexican History and Culture (pp. 83-118). Oxford: Blackwell Publishing Ltd.

-Casas Santasusana, E. (1954). Cómo se vende por anuncio. Barcelona: Juan Bruguer.

-Castillo, A. del (2006). Conceptos, imágenes y representaciones de la niñez en la ciudad de México, 1880-1920. México: Colmex/Instituto Mora.

-Curtis, A. (2009). Happiness machines [S. 1. Episode 1]. En A. Curtis, The Century of the self [Documental]. DVD. 59 min. BN Publishing.

-Freud, S., Jones, E. y Paskausk, R. A. (1993). The complete correspondence of Sigmund Freud and Ernest Jones, 1908-1939. Cambridge: Belknap Press of Harvard University Press.

Hellion, D. (2008). Exposición permanente: anuncios y anunciantes en El Mundo Ilustrado. México: INAH.

-Hepner, H. W. (1962). Publicidad moderna, principios y prácticas. México: UTEHA.

-Hunter, T. S. (1954). Nociones de publicidad. México: Aguilar.

\section{()(1)}


-Loyo Bravo, E. (2007). Gozos imaginados, sufrimientos reales: la vida cotidiana en la revista CROM, 1925-1930. En P. Gonzalbo Aizpuru y M. Bazant (coords.), Tradiciones y conflictos: Historia de la vida cotidiana en México e Hispanoamérica (pp. 349-384). México: Colmex.

-Matute, Á. (2006). De la tecnología al orden doméstico en el México de la posguerra. En Historia de la vida cotidiana en México (t. 5, vol. 2, pp. 157-176). México: ColmeX.

-Moreno, J. (2003). Yankee don t go home! Mexican nationalism, American business culture, and the shaping of modern Mexico, 19201950. North Carolina: Chapel Hill, The University of North Carolina Press.

-Ortiz Gaitán, J. (1998). Arte, publicidad y consumo en la prensa. Del porfirismo a la posrevolucion. Historia Mexicana, 48(2), 411-435.

-Ortiz Gaitán, J. (2003). Imágenes del deseo: arte y publicidad en la prensa ilustrada mexicana (1894-1939). México: UNAM.

-Ortiz Gaitán, J. (2006). Casa, vestido y sustento cultura material en anuncios de la prensa ilustrada (1894-1939). Historia de la vida cotidiana en México (t. 5, vol. 2, pp. 117-155). México: Colmex.

-Pretelin, C. (2010). Usted aprieta el botón, nosotros hacemos el resto. Anuncios de Cámaras Fotográficas Kodak 1888-1910 (Tesis de maestría). UNAM, México.

-Ramos Espinosa, A. (1952). El cuidado del niño y la moderna psicología: puericultura pedagó- gica del niño mexicano. México: s. e.

-Salvatore, R. (2005). Yankee advertising in Buenos Aires. Interventions: International Journal of Postcolonial Studies, 7, 216-235, Abingdon.

-Stearns, P. (2003). Anxious parents: a bistory of modern childrearing in America. Nueva York: New York University Press.

-Stearns, P. (2010). Defining happy childhoods: assessing a recent change. The Journal of the History of Childhood and Youth, 2(3), 165-186.

-Taylor, J. (1994). Kodak and the "English" market between the wars. Journal of Design History, 7(1), Oxford.

-Villamil Duarte, J. A. (1971). Publicidad mexicana: su historia sus instituciones sus hombres. México: Demoscopia.

-Woodard, J. P. (2002). Marketing modernity: The J. Walter Thompson Company and North American Advertising in Brazil, 19291939. Hispanic American Historical Review, 82, 257-290.

\section{OTRAS FUENTES}

\section{Hemerografía}

El Universal (1930-1970).

El Universal Gráfico (1931-1943).

Excélsior (1930-1956).

La Prensa (1932-1953).

Novedades (1941-1965). 